Letter Report

\title{
Yucca Mountain Environmental Monitoring Systems Initiative Air Quality Scoping Study for Tonopah Airport, Nye County, Nevada
}

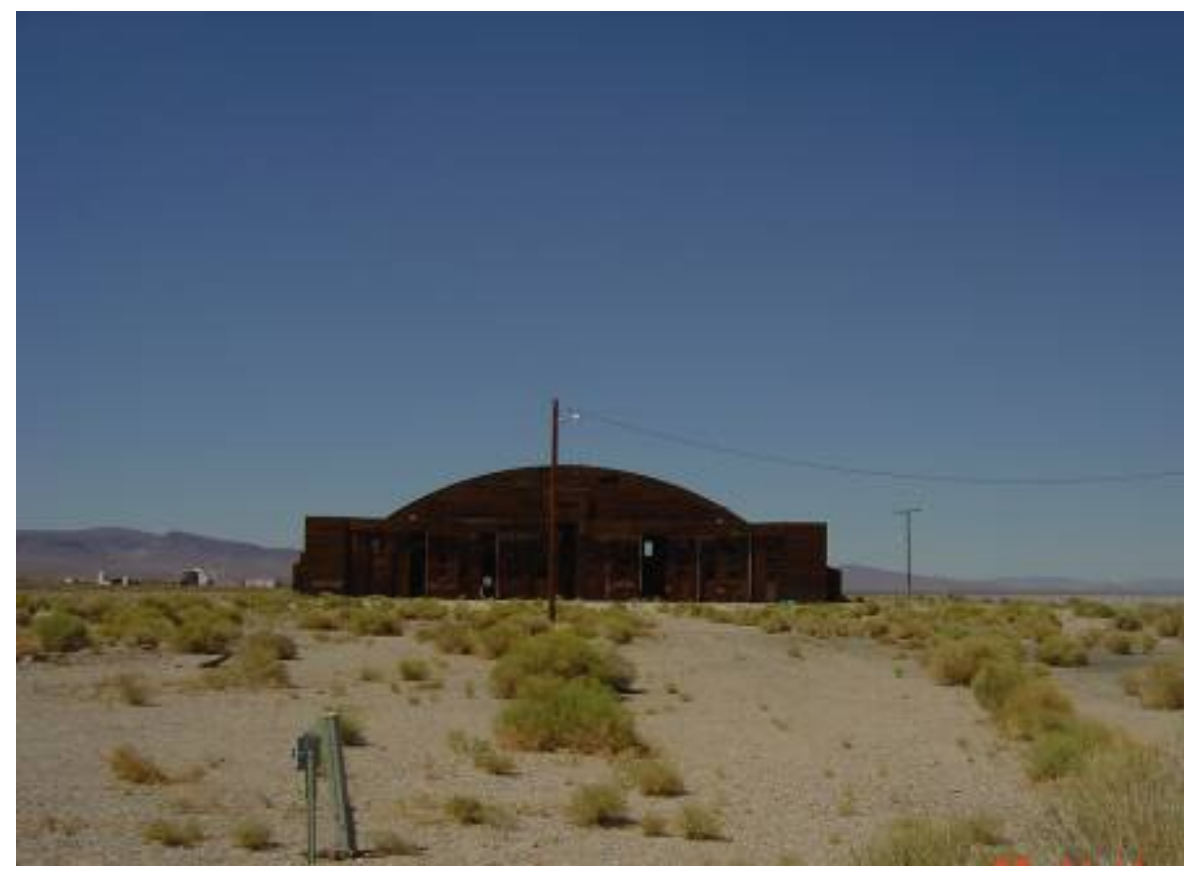

prepared by

Johann Engelbrecht, Ilias Kavouras, Dave Campbell, Scott Campbell, Steven Kohl and David Shafer Desert Research Institute

Nevada System of Higher Education

\author{
submitted to \\ Nevada Site Office \\ National Nuclear Security Administration \\ U.S. Department of Energy \\ Las Vegas, Nevada
}

August 2008

The work upon which this report is based was supported by the U.S. Department of Energy under Contract \#DE-AC52-06NA26383. 
Reference herein to any specific commercial product, process, or service by trade name, trademark, manufacturer, or otherwise, does not necessarily constitute or imply its endorsement, recommendation, or favoring by the United States Government or any agency thereof or its contractors or subcontractors. The views and opinions of authors expressed herein do not necessarily state or reflect those of the United States Government of any agency thereof.

This report has been reproduced directly from the best available copy.

Available for sale to the public, if paper, from:

\author{
U.S. Department of Commerce \\ National Technical Information Service \\ 5285 Port Royal Road \\ Springfield, VA 22161 \\ Phone: 800.553.6847 \\ Fax: 703.605.6900 \\ Email: orders@ntis.gov \\ Online ordering: http://www.ntis.gov/ordering.htm
}

Available electronically at http://www.osti.gov/bridge.

Available for a processing fee to the U.S. Department of Energy and its contractors, in paper, from:

U.S. Department of Energy

Office of Scientific and Technical Information

P.O. Box 62

Oak Ridge, TN 37831-0062

Phone: 865.576.8401

Fax: 865.576.5728

Email: reports@adonis.osti.gov 


\section{Erata Sheet}

\section{Yucca Mountain Environmental Monitoring Systems Initiative Air Quality Scoping Study for Caliente, Lincoln County, Nevada}

Page 3, 4th line from the bottom, date should read December 5, 2006

Page 21, caption should read: Figure 22. Wind direction and speed (mph) at Caliente.

Page 24, last para, last sentence should read: This may be explained by water-bound clay and organic particles.

\section{Yucca Mountain Environmental Monitoring Systems Initiative Air Quality Scoping Study for Crater Flat, Nye County, Nevada}

Page 6, Table 3, line 12, should be $\mathrm{Ca}^{2+}$

Page 18, caption should read: Figure 18. Wind direction and speed (mph) at Crater Flat.

Page 21, first paragraph line 6, date should be July 29, 2007

\section{Yucca Mountain Environmental Monitoring Systems Initiative Air Quality Scoping Study for Pahranagat National Wildlife Refuge, Lincoln County, Nevada}

Page 3, third line from bottom, date should read February 17, 2007

Page 6, Table 3, line 12, should be $\mathrm{Ca}^{2+}$

Page 21, caption should read: Figure 22. Wind direction and speed (mph) at Pahranagat NWR.

Page 22, line 9 should read: southeasterly and northerly winds (Figure 25 and Figure 26).

\section{Yucca Mountain Environmental Monitoring Systems Initiative Air Quality Scoping Study for Tonopah Airport, Nye County, Nevada}

Page 10, $3^{\text {rd }}$ line from the bottom, date should read August 29, 2007

Page 7, Table 3, line 5, should be $\mathrm{Ca}^{2+}$

Page 21, caption should read: Figure 22. Wind direction and speed (mph) at Tonopah Airport. 
THIS PAGE INTENTIONALLY LEFT BLANK 


\section{CONTENTS}

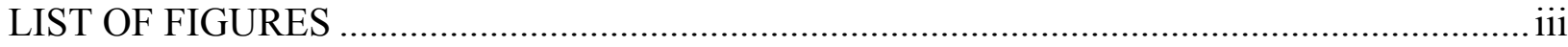

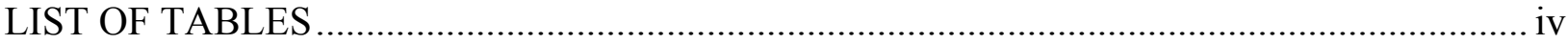

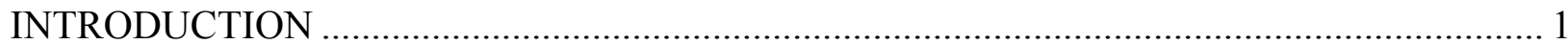

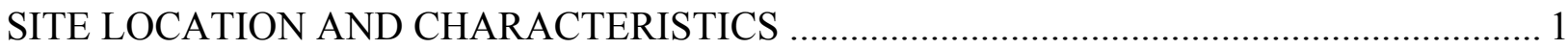

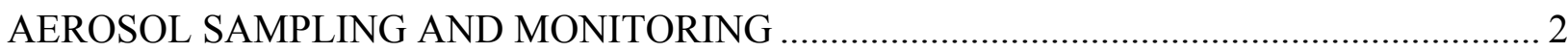

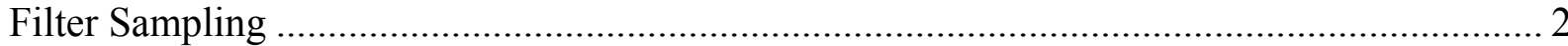

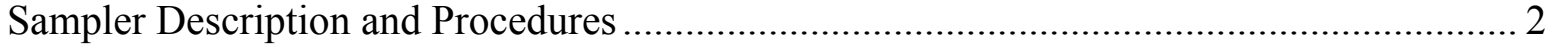

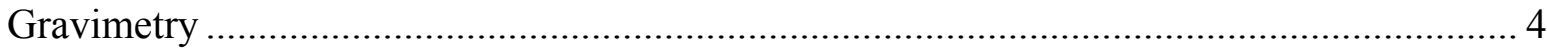

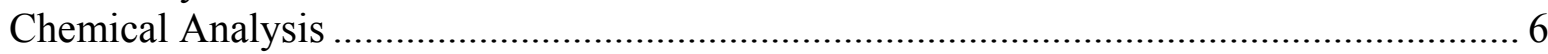

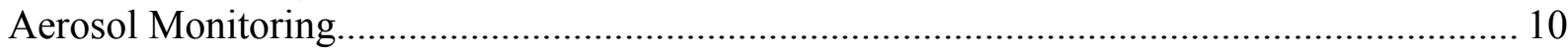

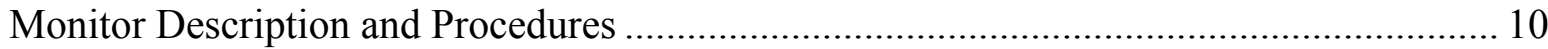

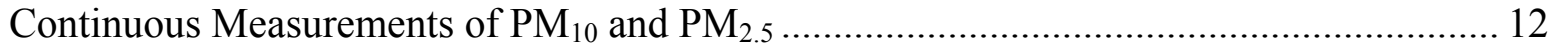

Comparison of Filter to Continuous Results...................................................................... 16

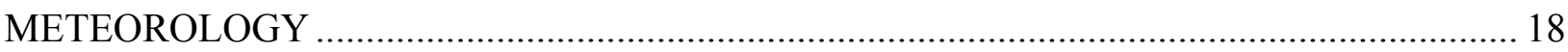

Relationships of Meteorology with Aerosol Measurements.................................................... 22

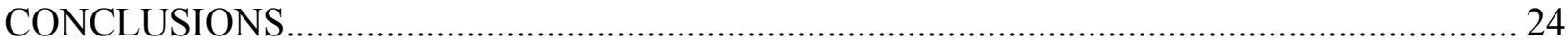

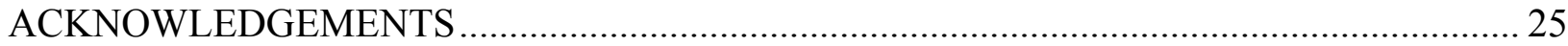

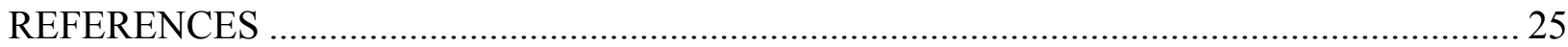

\section{LIST OF FIGURES}

1. Southern Nevada map showing the location of Site \#8 (at Tonopah Airport), Nevada Test Site, and Yucca Mountain.

2. Photographs of PQ100 (green/gray box in left photo), PQ200 (white box in left photo) and their sampling inlets (right photo)............................................................................ 2

3. A diagrammatic representation of the $\mathrm{BGI} \mathrm{PM}_{2.5}$ sampler showing the $\mathrm{PM}_{10}$ size selective impactor head as the first stage followed by a $\mathrm{PM}_{2.5}$ VSCC. ............................................... 3

4. Time series of $\mathrm{PM}_{10}$ and $\mathrm{PM}_{2.5}$ mass concentrations ( \pm uncertainty) at Site \#8 (Tonopah Airport). ................................................................................................................ 5

5. Relationship between mean ( \pm uncertainty) daily $\mathrm{PM}_{2.5}$ and $\mathrm{PM}_{10}$ at Tonopah Airport.......... 6

6. Reconstructed mass for $\mathrm{PM}_{10}$ and $\mathrm{PM}_{2.5}$ based on chemical composition. ............................ 10

7. Left photograph: The front panels of $\mathrm{PM}_{10}$ (right on the left photograph) and $\mathrm{PM}_{2.5}$ (left on the left photograph) of TEOM. Right photograph: The DustTrak monitors (green)

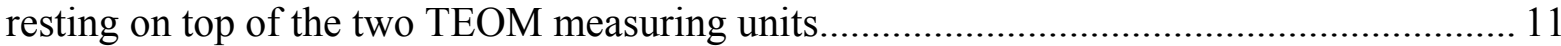

8. Schematic drawing of the sampling inlet for DUSTTRAK (not to scale)............................. 12

9. Mean 24-h $\mathrm{PM}_{10}$ and $\mathrm{PM}_{2.5}$ mass concentrations measured by TEOM at Site \#8 (Tonopah Airport).

10. $\mathrm{PM}_{2.5} / \mathrm{PM}_{10}$ mass ratios measured by TEOM at Site \#8 (Tonopah Airport)........................... 13

11. Variation of mean ( \pm st.error) $\mathrm{PM}_{10}$ and $\mathrm{PM}_{2.5}\left(\mu \mathrm{g} / \mathrm{m}^{3}\right)$ in weekdays and weekends at Site \#8 (Tonopah Airport) (Monday=1, Tuesday=2, Wednesday=3, Thursday=4, Friday=5, Saturday $=6$, Sunday $=7$ ). 
12. $\mathrm{PM}_{10}$ mass $\left(\mu \mathrm{g} / \mathrm{m}^{3}\right)$ measured with DUSTTRAK and TEOM at Site \#8 (Tonopah Airport).

13. $\mathrm{PM}_{2.5}$ mass $\left(\mu \mathrm{g} / \mathrm{m}^{3}\right)$ measured with DUSTTRAK and TEOM at Site \#8 (Tonopah Airport).

14. Comparison of 24-h $\mathrm{PM}_{10}$ and $\mathrm{PM}_{2.5}$ mass concentrations measured by TEOM and DUSTTRAK. Error bars represent the standard error of the mean.

15. Relationships between $\mathrm{PM}_{10}$ concentrations $\left(\mu \mathrm{g} / \mathrm{m}^{3}\right)$ measured by TEOM, DUSTTRAK, and filter-based methods.

16. Relationships between $\mathrm{PM}_{2.5}$ concentrations $\left(\mu \mathrm{g} / \mathrm{m}^{3}\right)$ measured by TEOM, DUSTTRAK, and filter-based methods.

17. Solar radiation (in watts $/ \mathrm{m}^{2}$ ) at Site $\# 8$ (Tonopah Airport) . ............................................ 18

18. Temperature (in ${ }^{\circ} \mathrm{F}$ ) and relative humidity at Site \#8 (Tonopah Airport)........................... 19

19. Total precipitation (in $\mathrm{mm}$ ) at Site \#8 (Tonopah Airport) ................................................. 19

20. Wind speed (in miles/hr) at Site \#8 (Tonopah Airport) ................................................. 20

21. Wind direction at Site \#8 (Tonopah Airport) ........................................................... 20

22. Wind direction and speed at Tonopah Airport............................................................ 21

23. Average wind speed for each wind direction sector.................................................. 22

24. Hourly variation of $\mathrm{PM}_{10}$ and $\mathrm{PM}_{2.5}$ mass concentrations $\left(\mu \mathrm{g} / \mathrm{m}^{3}\right)$ as well as wind speed (miles/hour) at Site \#8 (Tonopah Airport).

25. Mean ( \pm st.error) of $\mathrm{PM}_{10}$ mass concentrations $\left(\mu \mathrm{g} / \mathrm{m}^{3}\right)$ for different wind direction

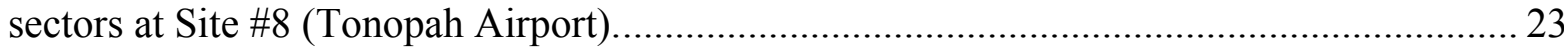

26. Mean ( \pm st.error) of $\mathrm{PM}_{2.5}$ mass concentrations $\left(\mu \mathrm{g} / \mathrm{m}^{3}\right)$ for different wind direction sectors at Site \#8 (Tonopah Airport)

\section{LIST OF TABLES}

1. Longitude, latitude, and elevation of the mobile trailer location at Site \#8 (Tonopah Airport).

2. Collection day, filter number, mass, and uncertainty determined by gravimetric analysis and associated flags of samples at Site \#8 (Tonopah Airport).

3. Results of the chemical analysis for selected filters from Tonopah Airport........................... 6

4. Statistics for 24-h $\mathrm{PM}_{10}$ and $\mathrm{PM}_{2.5}$ TEOM mass concentrations..................................... 12

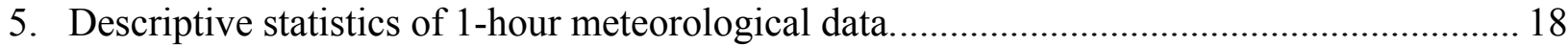

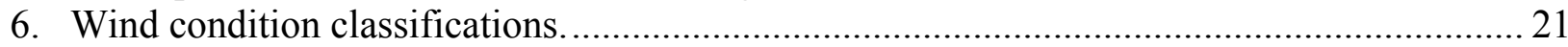




\section{INTRODUCTION}

The Desert Research Institute (DRI) is performing a scoping study as part of the U.S. Department of Energy's Yucca Mountain Environmental Monitoring Systems Initiative (EMSI). The main objective is to obtain baseline air quality information for Yucca Mountain and an area surrounding the Nevada Test Site (NTS).

Air quality and meteorological monitoring and sampling equipment housed in a mobile trailer (shelter) is collecting data at eight sites outside the NTS, including Ash Meadows National Wildlife Refuge (NWR), Tonopah Airport, Beatty, Rachel, Caliente, Pahranagat NWR, Crater Flat, and the Tonopah Airport, and at four sites on the NTS (Engelbrecht et al., 2007a-d). The trailer is stationed at any one site for approximately eight weeks at a time.

This letter report provides a summary of air quality and meteorological data, on completion of the site's sampling program.

\section{SITE LOCATION AND CHARACTERISTICS}

Tonopah Airport is located 7 miles east of the town of Tonopah, Nevada, along U.S Route 6 . The population of Tonopah is approximately 2,627 and covers a total area of 16.2 square miles. It is located in the hills of the San Antonio range at about 6,030 ft elevation. The airport is about 286 miles north of Las Vegas and about 95 miles north of the proposed Yucca Mountain repository (Figure 1).

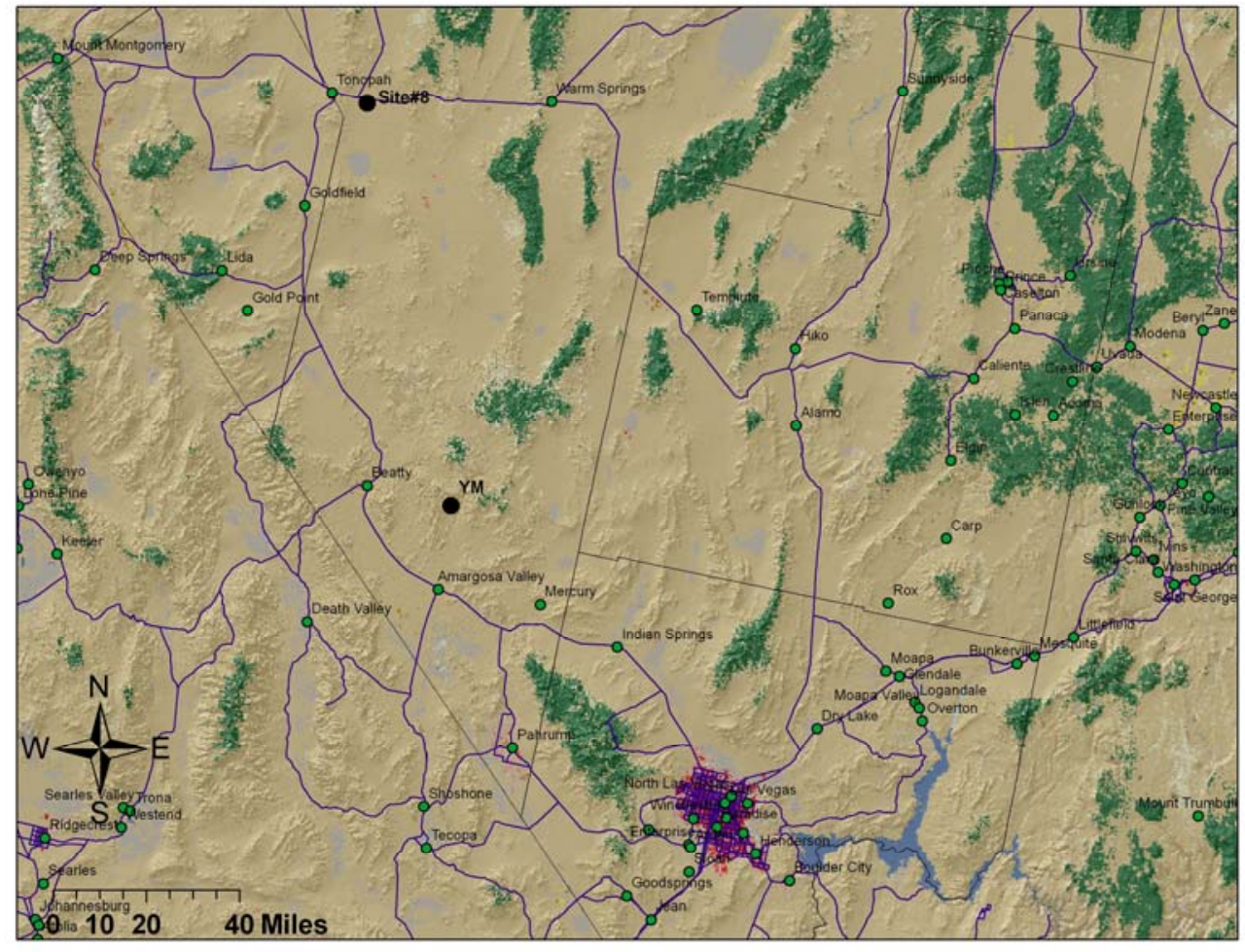

Figure 1. Southern Nevada map showing the location of Site \#8 (at Tonopah Airport), Nevada Test Site, and Yucca Mountain. The map background is land use and land cover from the 2001 National Land Cover Database. 
The mobile trailer was located adjacent to Tonopah Airport on the south end of the runway about 1.6 miles south of U.S. Route 6. Monitoring of $\mathrm{PM}_{10}, \mathrm{PM}_{2.5}$, and meteorological conditions was carried out from August 29, 2007, to December 19, 2007.

Table 1. Longitude, latitude, and elevation of the mobile trailer location at Site \#8 (Tonopah Airport).

\begin{tabular}{cc}
\hline Site & Tonopah Airport \\
\hline Latitude & $38^{\circ} 31^{\prime} 33^{\prime \prime}$ \\
Longitude & $117^{\circ} 56^{\prime} 45^{\prime \prime}$ \\
\hline
\end{tabular}

\section{AEROSOL SAMPLING AND MONITORING}

\section{Filter Sampling}

\section{Sampler Description and Procedures}

BGI, Inc., PQ100 and PQ200 Ambient PM 2.5 Federal Reference Method (FRM) samplers were used to collect 24-h integrated $\mathrm{PM}_{10}$ and $\mathrm{PM}_{2.5}$ samples. Figure 2 shows the PQ100 and PQ200 in the mobile trailer (left) and the $\mathrm{PM}_{10}$ sampling inlets on the top of the trailer (right). Both the PQ100 (Designation No. RFPS-1298-124) and PQ200 (Designation No. RFPS-0498-116) samplers are designed to meet the criteria for collecting 24-h samples of ambient aerosol according to the U.S. National Ambient Air Quality Standards (NAAQS).

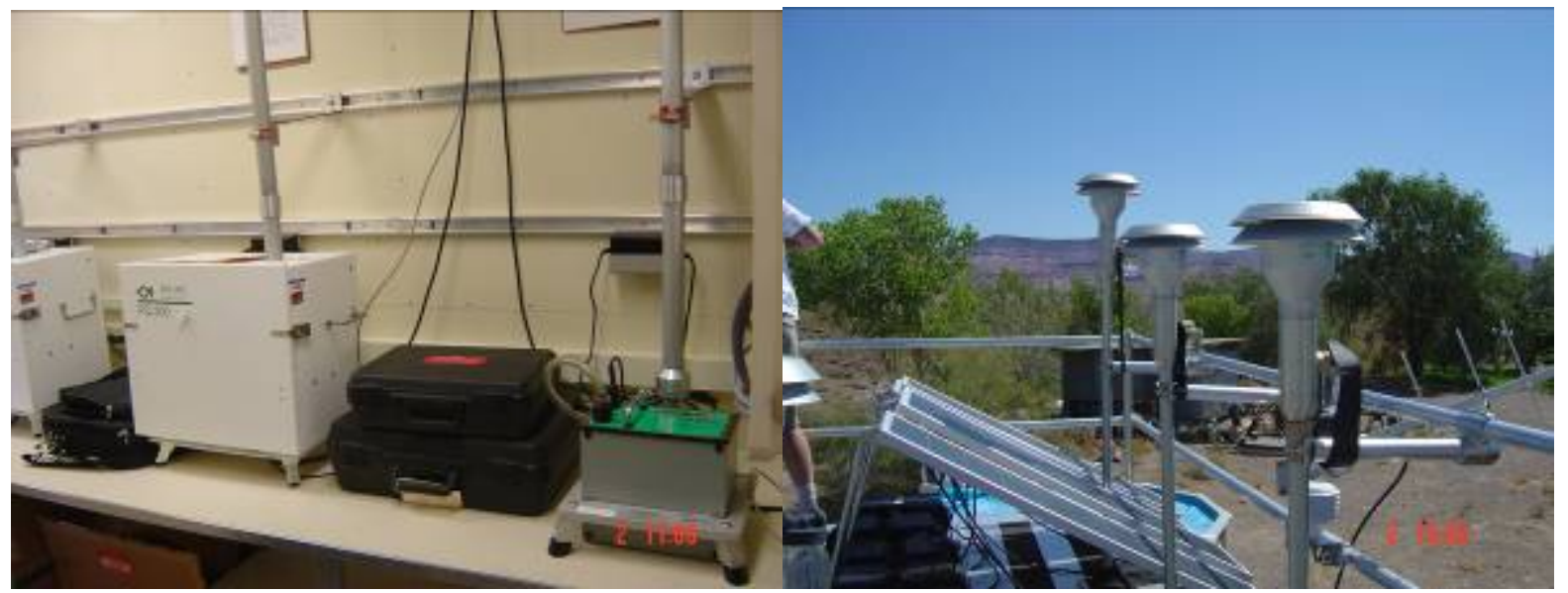

Figure 2. Photographs of PQ100 (green/gray box in left photo), PQ200 (white box in left photo) and their sampling inlets (right photo).

Figure 3 shows a schematic drawing of the samplers. Particles with aerodynamic diameter larger than $10 \mu \mathrm{m}$ were removed by impaction at the $\mathrm{PM}_{10}$ size selective inlet. For the $\mathrm{PM}_{10}$ fraction, particles were then collected by a filter located downstream of the size selective inlet. For the collection of $\mathrm{PM}_{2.5}$, particles in the range between 2.5 and $10 \mu \mathrm{m}$ were removed by the Very Sharp Cut Cyclone (VSCC) (U.S. Environmental Protection Agency [EPA] Equivalent Designation No. EQPM-0202-142), then collected on a filter. 


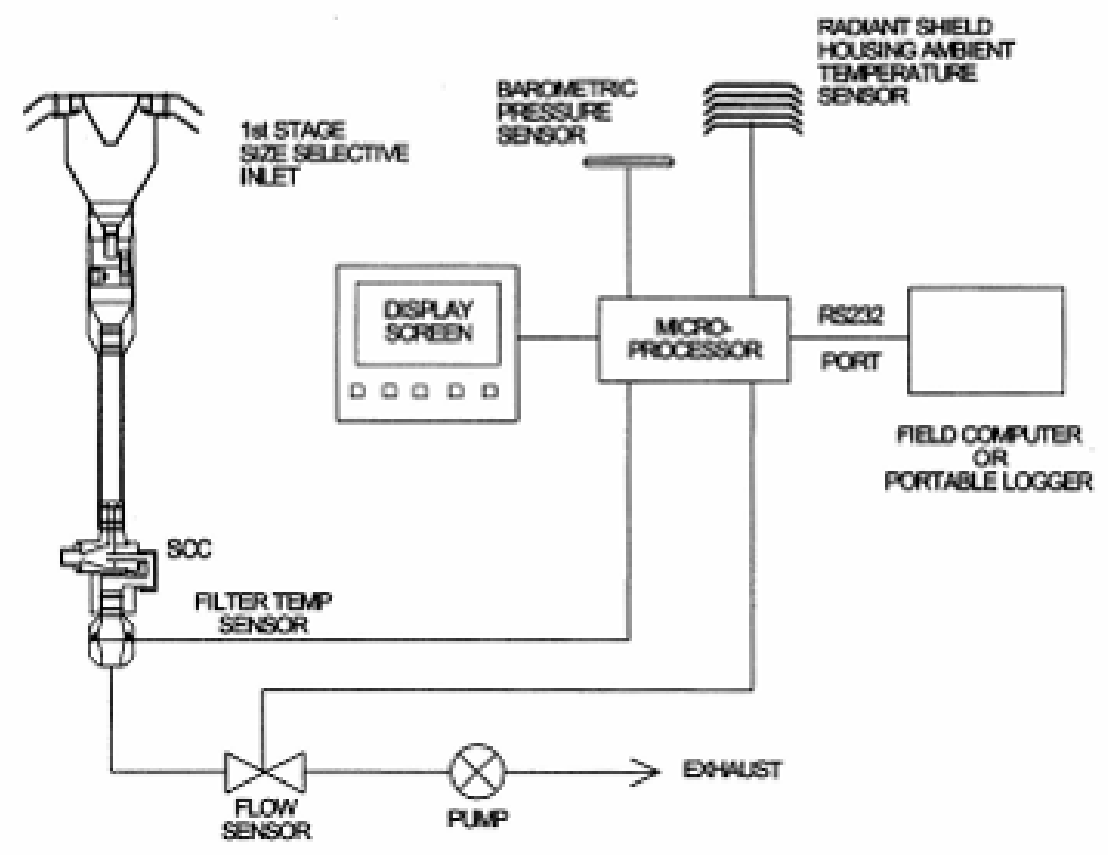

Figure 3. A diagrammatic representation of the $\mathrm{BGI} \mathrm{PM}_{2.5}$ sampler showing the $\mathrm{PM}_{10}$ size selective impactor head as the first stage followed by a $\mathrm{PM}_{2.5}$ VSCC. This configuration can be readily modified to a $\mathrm{PM}_{10}$ sampler by removal of the VSCC.

For both PQ100 and PQ200, samples were collected at a volumetric flow rate of 16.67 liters $/ \mathrm{min}$. The flow rate is controlled to \pm 2 percent precision with a mass flow controller. The actual ambient temperature and barometric pressure, filter temperature and pressure, and anomalies (if any) were recorded (and controlled) by a microprocessor. The sampler was equipped to operate from an internal 12-volt DC battery. The battery was recharged by a battery charger from 120-volt AC. Alternatively, a 32-watt solar panel with an additional external ballast battery was installed to provide power for periods without electricity. Two sets of PQ100 and PQ200 samplers were installed in the mobile trailer. $\mathrm{PM}_{10}$ and $\mathrm{PM}_{2.5}$ samples were collected on filters in numbered cassettes, labeled TT (for $\mathrm{PM}_{10}$ Teflon), FT (for $\mathrm{PM}_{2.5}$ Teflon), TQ (for $\mathrm{PM}_{10}$ Quartz), and FQ (for $\mathrm{PM}_{2.5}$ Quartz). Each filter cassette was loaded with a pre-weighed 46.2-mm-diameter PTFE (Teflon) membrane filter (Whatman \# 7592-004) or 47-mm quartz fiber (Pallflex \#2500QAT-UP) filter. The Teflon membrane collected particles for measurement of mass by gravimetric analysis, light absorption by densitometry, and elements by x-ray fluorescence spectrometry. Quartz fiber filters were used for measurement of water-soluble ions by atomic absorption spectrometry, ion chromatography, and automated colorimetry, and also for measurement of carbon species by thermal optical reflectance.

Operation, calibration, and maintenance of PQ100 and PQ200 are described in standard operating procedure (SOP) "BGI PQ100 PM10 and PQ200 PM2.5 REFERENCE SAMPLERS FOR THE YUCCA MOUNTAIN AIR QUALITY PROGRAM.” Flow calibration and leak tests (only for PQ200) were performed on the day of installation (August 29, 2007). The leak check was performed according to the manufacturer's operational instruction manual only for PQ200; no manufacturer's procedure exists for the 
PQ100. The flow rate was calibrated using a BGI Tri-Cal calibrator. The sampler was then placed in calibration or "run" mode and a one-point calibration verification or one-point flow-rate verification was performed. Aerosol samples were collected on a 1-in-6-day schedule. Audits of the flow and leak tests were done onsite at the beginning and end of the monitoring campaign. Teflon and quartz filters were prepared and assembled in their filter holders in the Desert Research Institute's (DRI) Environmental Analysis Facility (EAF) in Reno and shipped to DRI's facilities in Las Vegas. The filters were kept at $-4^{\circ} \mathrm{C}$ and transported to the field in a cryo-cooler. Exposed filters were also stored at $-4^{\circ} \mathrm{C}$ in Las Vegas. Upon completion of the monitoring period at the site, all filters were shipped to the EAF in Reno.

\section{Gravimetry}

Table 2 shows mass concentrations (and uncertainty) of filters collected at the Tonopah Airport. $\mathrm{PM}_{10}$ mass concentrations varied from $0.54 \mu \mathrm{g} / \mathrm{m}^{3}$ to $19.76 \mu \mathrm{g} / \mathrm{m}^{3}$, while $\mathrm{PM}_{2.5}$ mass concentrations ranged from $0.21 \mu \mathrm{g} / \mathrm{m}^{3}$ to $15.94 \mu \mathrm{g} / \mathrm{m}^{3}$. Similar temporal trends were observed for both $\mathrm{PM}_{10}$ and $\mathrm{PM}_{2.5}$. In all cases, 24-h $\mathrm{PM}_{10}$ and $\mathrm{PM}_{2.5}$ levels were significantly lower than the daily and annual NAAQS as recently revised by EPA (24-h PM $10: 150 \mu \mathrm{g} / \mathrm{m}^{3}, 24-\mathrm{h} \mathrm{PM}_{2.5}: 35 \mu \mathrm{g} / \mathrm{m}^{3}$; Annual $\mathrm{PM}_{2.5}: 15 \mu \mathrm{g} / \mathrm{m}^{3}$ ) (Figure 4). Fine particles $\left(\mathrm{PM}_{2.5}\right)$ accounted for approximately two-thirds of $\mathrm{PM}_{10}\left(\mathrm{PM}_{2.5} / \mathrm{PM}_{10}\right.$ ratio of 0.64$)$ (Figure 5). This value was comparable to that observed for traffic sites in urban areas probably due to the contribution of traffic emissions from U.S. Highway 6 and the nearby airport. However, note that $\mathrm{PM}_{10}$ and $\mathrm{PM}_{2.5}$ concentration levels are quite low, which indicates the moderate-to-low contribution of windblown dust sources at Tonopah Airport for the monitoring period.

Table 2. Collection day, filter number, mass, and uncertainty determined by gravimetric analysis and associated flags of samples at Site \#8 (Tonopah Airport).

\begin{tabular}{|c|c|c|c|c|c|}
\hline Date & No & Type & $\begin{array}{c}\text { Mass } \\
\left(\mu \mathrm{g} / \mathrm{m}^{3}\right)\end{array}$ & $\begin{array}{c}\text { Uncertainty } \\
\left(\mu \mathrm{g} / \mathrm{m}^{3}\right)\end{array}$ & Flags \\
\hline \multirow{2}{*}{$9 / 03 / 2007$} & \multirow{2}{*}{106} & $\mathrm{PM}_{10}$ & 11.7304 & 0.4877 & \\
\hline & & $\mathrm{PM}_{2.5}$ & 5.1165 & 0.4397 & \\
\hline \multirow{2}{*}{$9 / 09 / 2007$} & \multirow{2}{*}{107} & $\mathrm{PM}_{10}$ & 10.6073 & 0.4773 & \\
\hline & & $\mathrm{PM}_{2.5}$ & 6.5308 & 0.4471 & \\
\hline \multirow{2}{*}{$9 / 15 / 2007$} & \multirow{2}{*}{108} & $\mathrm{PM}_{10}$ & 4.4925 & 0.4369 & \\
\hline & & $\mathrm{PM}_{2.5}$ & 3.4942 & 0.4333 & \\
\hline \multirow{2}{*}{$9 / 21 / 2007$} & \multirow{2}{*}{109} & $\mathrm{PM}_{10}$ & 6.4060 & 0.4464 & \\
\hline & & $\mathrm{PM}_{2.5}$ & 2.2888 & 0.4302 & \\
\hline \multirow{2}{*}{$9 / 27 / 2007$} & \multirow{2}{*}{110} & $\mathrm{PM}_{10}$ & 7.7787 & 0.4550 & \\
\hline & & $\mathrm{PM}_{2.5}$ & 2.7038 & 0.4310 & \\
\hline \multirow{2}{*}{$10 / 03 / 2007$} & \multirow{2}{*}{111} & $\mathrm{PM}_{10}$ & 3.9102 & 0.4347 & \\
\hline & & $\mathrm{PM}_{2.5}$ & 0.2080 & 0.4276 & \\
\hline \multirow{2}{*}{$10 / 09 / 2007$} & \multirow{2}{*}{112} & $\mathrm{PM}_{10}$ & 3.6575 & 0.4335 & \\
\hline & & $\mathrm{PM}_{2.5}$ & 1.9975 & 0.4296 & \\
\hline \multirow{2}{*}{$10 / 15 / 2007$} & \multirow{2}{*}{113} & $\mathrm{PM}_{10}$ & 3.4942 & 0.4333 & \\
\hline & & $\mathrm{PM}_{2.5}$ & 2.5385 & 0.4308 & \\
\hline \multirow{2}{*}{$10 / 21 / 2007$} & \multirow{2}{*}{114} & $\mathrm{PM}_{10}$ & 1.0815 & 0.4282 & \\
\hline & & $\mathrm{PM}_{2.5}$ & 0.5410 & 0.4279 & \\
\hline \multirow{2}{*}{$10 / 27 / 2007$} & \multirow{2}{*}{115} & $\mathrm{PM}_{10}$ & 19.5785 & 0.5822 & \\
\hline & & $\mathrm{PM}_{2.5}$ & 15.9384 & 0.5335 & \\
\hline $11 / 02 / 2007$ & 117 & $\mathrm{PM}_{10}$ & -99.0000 & -99.0000 & B: Field blanks \\
\hline
\end{tabular}


Table 2. Collection day, filter number, mass, and uncertainty determined by gravimetric analysis and associated flags of samples at Site \#8 (Tonopah Airport) (continued).

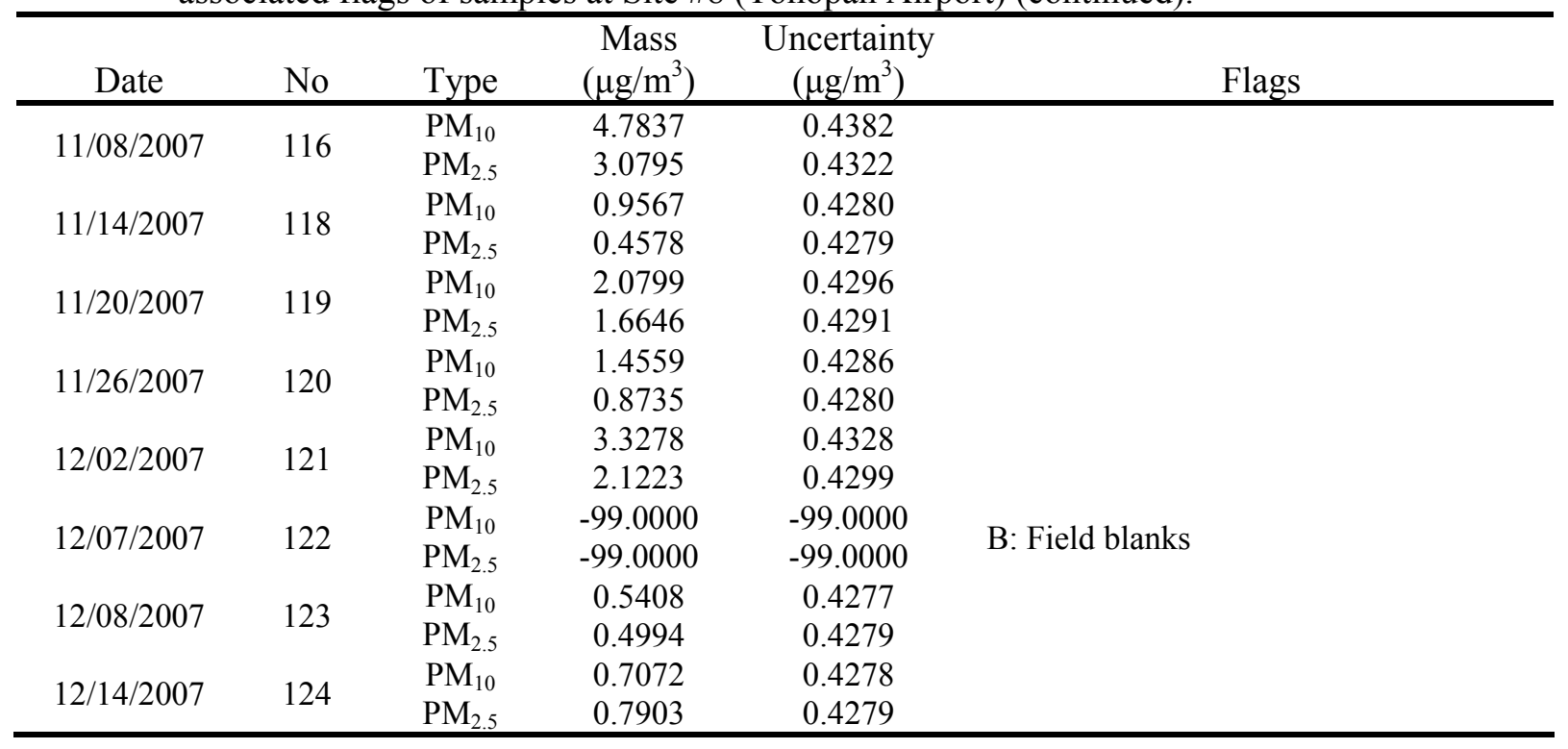

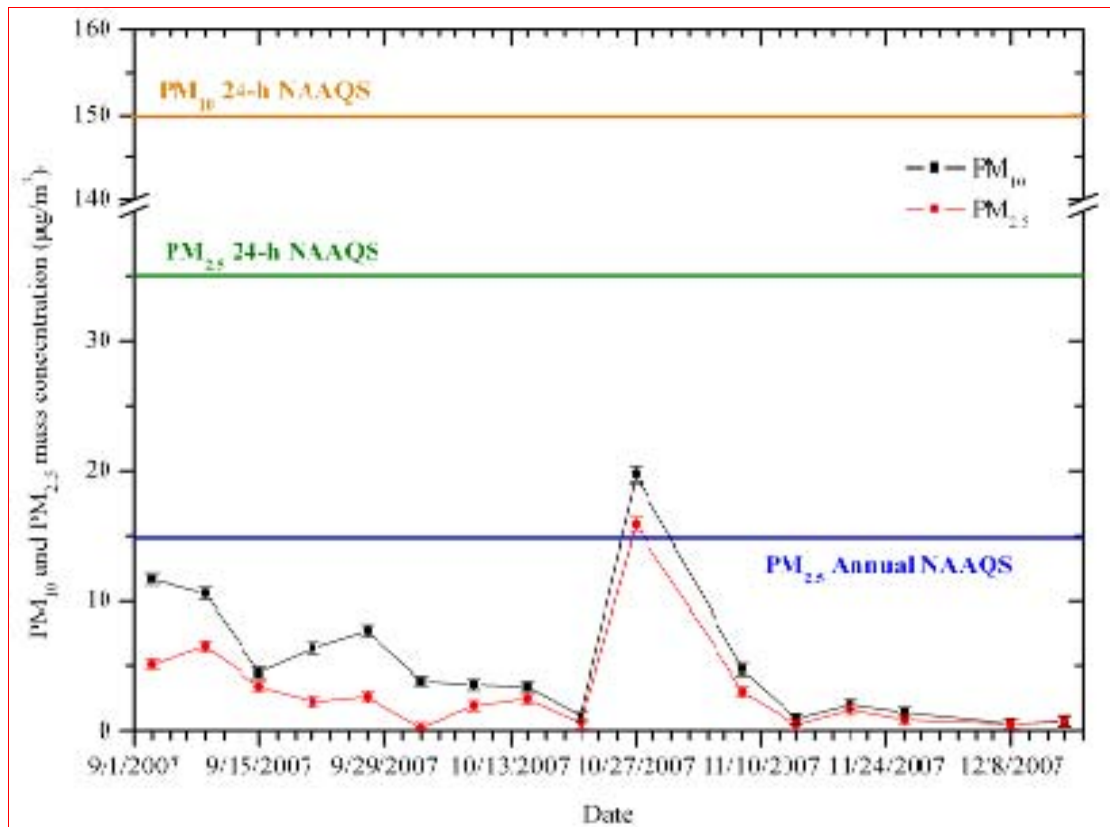

Figure 4. Time series of $\mathrm{PM}_{10}$ and $\mathrm{PM}_{2.5}$ mass concentrations ( \pm uncertainty) at Site $\# 8$ (Tonopah Airport). 


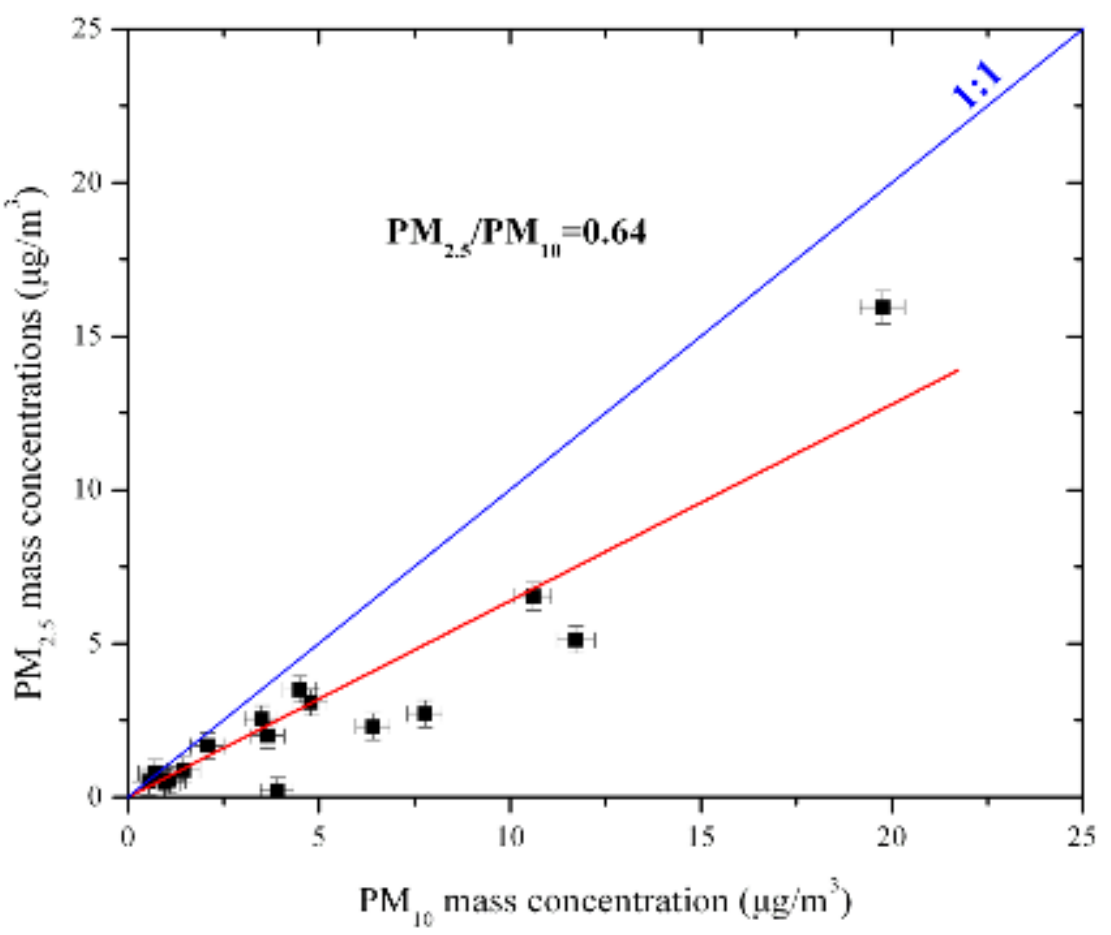

Figure 5. Relationship between mean ( \pm uncertainty) daily $\mathrm{PM}_{2.5}$ and $\mathrm{PM}_{10}$ at Tonopah Airport.

\section{Chemical Analysis}

Table 3 shows the chemical content of $\mathrm{PM}_{10}$ and $\mathrm{PM}_{2.5}$ samples collected on October 27, 2007, and November 8, 2007. Chemical analysis included elements (from sodium to uranium) with x-ray fluorescence spectrometry (XRF), major anions (sulfate, nitrate, and chloride) by ion chromatography (IC), major cations (sodium, potassium) by atomic absorption (AA), particulate ammonium by automated colorimetry (AC), and elemental and organic carbon by thermal optical reflectance (TOR).

Table 3. Results of the chemical analysis for selected filters from Tonopah Airport. Chemical components with concentration higher than two times the uncertainty are in bold, while those with concentrations lower than two times the uncertainty are in italics. Concentrations are in $\mu \mathrm{g} / \mathrm{m}^{3}$.

\begin{tabular}{lrrrrrrrr}
\hline DATE & \multicolumn{4}{c}{$10 / 27 / 2007$} & \multicolumn{3}{c}{$11 / 08 / 2007$} \\
SIZE & \multicolumn{2}{c}{$\mathrm{PM}_{10}$} & \multicolumn{2}{c}{$\mathrm{PM}_{2.5}$} & \multicolumn{2}{c}{$\mathrm{PM}_{10}$} & $\mathrm{PM}_{2.5}$ \\
& Conc. & Uncer. & Conc. & Uncer. & Conc. & Uncer. & Conc. & Uncer. \\
\hline Mass & $\mathbf{1 9 . 5 7 8 5}$ & $\mathbf{0 . 5 8 2 2}$ & $\mathbf{1 5 . 9 3 8 4}$ & $\mathbf{0 . 5 3 3 5}$ & $\mathbf{4 . 7 8 3 7}$ & $\mathbf{0 . 4 3 8 2}$ & $\mathbf{3 . 0 7 9 5}$ & $\mathbf{0 . 4 3 2 2}$ \\
\hline Chloride, $\mathrm{Cl}^{-}$ & 0.0483 & 0.0297 & 0.0355 & 0.0296 & 0 & 0.0294 & 0.039 & 0.0296 \\
Nitrate, $\mathrm{NO}_{3}{ }^{-}$ & $\mathbf{0 . 5 8 6 5}$ & $\mathbf{0 . 0 3 5 1}$ & $\mathbf{0 . 3 4 9 3}$ & $\mathbf{0 . 0 3 1 7}$ & $\mathbf{0 . 1 5 9}$ & $\mathbf{0 . 0 3}$ & $\mathbf{0 . 0 1 4 3}$ & $\mathbf{0 . 0 2 9 5}$ \\
Sulfate, $\mathrm{SO}_{4}{ }^{2-}$ & $\mathbf{0 . 8 3 7 5}$ & $\mathbf{0 . 0 3 4 6}$ & $\mathbf{0 . 7 5 5 8}$ & $\mathbf{0 . 0 3 3 7}$ & $\mathbf{1 . 0 8 3 6}$ & $\mathbf{0 . 0 3 7 7}$ & $\mathbf{1 . 0 7 6 6}$ & $\mathbf{0 . 0 3 7 6}$ \\
Ammonium, $\mathrm{NH}_{4}^{+}$ & $\mathbf{0 . 4 4 1}$ & $\mathbf{0 . 0 3 3 5}$ & $\mathbf{0 . 3 7 9 9}$ & $\mathbf{0 . 0 3 2 6}$ & $\mathbf{0 . 3 9 4 2}$ & $\mathbf{0 . 0 3 2 8}$ & $\mathbf{0 . 3 9 6 2}$ & $\mathbf{0 . 0 3 2 8}$ \\
Sodium, $\mathrm{Na}^{+}$ & 0.055 & 0.0058 & 0.023 & 0.0056 & 0.0146 & 0.0056 & 0.0145 & 0.0056 \\
Magnesium, $\mathrm{Mg}^{2+}$ & $\mathbf{0 . 0 4 3 3}$ & $\mathbf{0 . 0 0 1 7}$ & $\mathbf{0 . 0 0 6 4}$ & $\mathbf{0 . 0 0 1 2}$ & $\mathbf{0 . 0 1 1 1}$ & $\mathbf{0 . 0 0 1 2}$ & $\mathbf{0 . 0 0 3 7}$ & $\mathbf{0 . 0 0 1 2}$ \\
\hline
\end{tabular}


Table 3. Results of the chemical analysis for selected filters from Tonopah Airport. Chemical components with concentration higher than two times the uncertainty are in bold, while those with concentrations lower than two times the uncertainty are in italics. Concentrations are in $\mu \mathrm{g} / \mathrm{m}^{3}$ (continued).

\begin{tabular}{|c|c|c|c|c|c|c|c|c|}
\hline \multirow{3}{*}{$\begin{array}{l}\text { DATE } \\
\text { SIZE }\end{array}$} & \multicolumn{4}{|c|}{$10 / 27 / 2007$} & \multicolumn{4}{|c|}{$11 / 08 / 2007$} \\
\hline & \multicolumn{2}{|c|}{$\mathrm{PM}_{10}$} & \multicolumn{2}{|c|}{$\mathrm{PM}_{2.5}$} & \multicolumn{2}{|c|}{$\mathrm{PM}_{10}$} & \multicolumn{2}{|c|}{$\mathrm{PM}_{2.5}$} \\
\hline & Conc. & Uncer. & Conc. & Uncer. & Conc. & Uncer. & Conc. & Uncer. \\
\hline Potassium, $\mathrm{K}^{+}$ & 0.2576 & 0.007 & 0.2133 & 0.0061 & 0.0201 & 0.003 & 0.0163 & 0.003 \\
\hline Calcium, $\mathrm{Ca}_{2+}$ & 0.3978 & 0.0181 & 0.0455 & 0.0153 & 0.1609 & 0.0158 & 0.0259 & 0.0153 \\
\hline $\mathrm{OC} 1$ & 0.1351 & 0.0564 & 0.3043 & 0.1198 & 0 & 0.0208 & 0.0741 & 0.0355 \\
\hline $\mathrm{OC} 2$ & 1.0346 & 0.2432 & 1.2721 & 0.2937 & 0.0789 & 0.0569 & 0.3265 & 0.0976 \\
\hline OC3 & 2.2191 & 0.3449 & 2.2645 & 0.3501 & 0.1629 & 0.1521 & 0.2347 & 0.1558 \\
\hline $\mathrm{OC} 4$ & 1.2165 & 0.1358 & 1.245 & 0.1385 & 0.0787 & 0.0523 & 0.1134 & 0.0532 \\
\hline Pyrolyzed OC-TT & 2.1507 & 0.7331 & 2.0421 & 0.6962 & 0.0612 & 0.0424 & 0.055 & 0.0414 \\
\hline Pyrolyzed OC-Op & 1.7488 & 0.6216 & 1.5809 & 0.5622 & 0.0399 & 0.0396 & $\mathbf{0}$ & 0.037 \\
\hline Total OC & 6.3541 & 0.6036 & 6.6669 & 0.6287 & 0.3604 & 0.2092 & 0.7488 & 0.2214 \\
\hline EC1 & 2.4554 & 0.5597 & 2.4218 & 0.5521 & 0.0612 & 0.031 & 0.0671 & 0.0317 \\
\hline $\mathrm{EC} 2$ & 0.1938 & 0.0766 & 0.229 & 0.0878 & 0 & 0.0346 & 0 & 0.0347 \\
\hline EC3 & 0 & 0.0115 & 0 & 0.0115 & 0 & 0.0115 & 0 & 0.0115 \\
\hline Total EC & 0.9005 & 0.178 & 1.0699 & 0.2097 & 0.0213 & 0.0441 & 0.0671 & 0.0458 \\
\hline Total Carbon & 7.3173 & 0.7064 & 7.7368 & 0.7414 & 0.4047 & 0.2285 & 0.8159 & 0.2419 \\
\hline $\begin{array}{l}\text { Carbonate Carbon } \\
\left(\mathrm{CO}_{3}{ }^{2-}\right)\end{array}$ & 0.0626 & 0.2156 & 0 & 0.2149 & 0.023 & 0.2149 & 0 & 0.215 \\
\hline Sodium, $\mathrm{Na}$ & 0.2117 & 0.0836 & 0.0776 & 0.0815 & 0.0606 & 0.0812 & 0.089 & 0.0817 \\
\hline Magnesium, Mg & 0.1159 & 0.0436 & 0.023 & 0.0431 & 0.0435 & 0.0432 & 0.0102 & 0.043 \\
\hline Aluminum, $\mathrm{Al}$ & 0.2366 & 0.0094 & 0.0868 & 0.0077 & 0.106 & 0.0079 & 0.0468 & 0.0074 \\
\hline Silicon, $\mathrm{Si}$ & 0.5984 & 0.0159 & 0.199 & 0.0095 & 0.2826 & 0.0106 & 0.1067 & 0.0086 \\
\hline Phosphorous, $\mathrm{P}$ & 0.0155 & 0.003 & 0.0139 & 0.003 & 0.0164 & 0.003 & 0.0168 & 0.003 \\
\hline Sulfur, $\mathrm{S}$ & 0.2177 & 0.0133 & 0.2276 & 0.0134 & 0.3791 & 0.0151 & 0.3647 & 0.0149 \\
\hline Chlorine, $\mathrm{Cl}$ & 0.016 & 0.0016 & 0.0085 & 0.0016 & 0 & 0.0016 & 0 & 0.0016 \\
\hline Potassium, K & 0.3681 & 0.0077 & 0.2867 & 0.0061 & 0.0629 & 0.002 & 0.027 & 0.0016 \\
\hline Calcium, $\mathrm{Ca}$ & 0.3514 & 0.0074 & 0.0939 & 0.0027 & 0.1341 & 0.0033 & 0.0421 & 0.0021 \\
\hline Scandium, Sc & 0 & 0.0058 & 0 & 0.0058 & 0 & 0.0058 & 0 & 0.0058 \\
\hline Titanium, Ti & 0.0219 & 0.0012 & 0.0076 & 0.0011 & 0.0106 & 0.0011 & 0.0038 & 0.0011 \\
\hline Vanadium, V & 0.0007 & 0.0001 & 0 & 0.0001 & 0.0004 & 0.0001 & 0 & 0.0001 \\
\hline Chromium, $\mathrm{Cr}$ & 0 & 0.001 & 0 & 0.001 & 0 & 0.001 & 0 & 0.001 \\
\hline Manganese, Mn & 0.0075 & 0.0021 & 0.0023 & 0.0021 & 0.0022 & 0.0021 & 0.0002 & 0.0021 \\
\hline Iron, $\mathrm{Fe}$ & 0.2008 & 0.0051 & 0.0443 & 0.0031 & 0.0614 & 0.0033 & o & 0.0029 \\
\hline Cobalt, Co & 0 & 0.0001 & 0 & 0.0001 & 0 & 0.0001 & 0 & 0.0001 \\
\hline Nickel, Ni & 0 & 0.0006 & 0 & 0.0006 & 0 & 0.0006 & 0 & 0.0006 \\
\hline Copper, $\mathrm{Cu}$ & 0.0022 & 0.0009 & 0.0014 & 0.0009 & 0.0011 & 0.0009 & 0.0008 & 0.0009 \\
\hline Zinc, Zn & 0.0061 & 0.0009 & 0.0053 & 0.0009 & 0.0004 & 0.0009 & 0.0026 & 0.0009 \\
\hline Gallium, Ga & 0.0017 & 0.0031 & 0 & 0.0031 & 0.0008 & 0.0031 & 0.0014 & 0.0031 \\
\hline Arsenic, As & 0 & 0.0001 & 0 & 0.0001 & 0 & 0.0001 & 0 & 0.0001 \\
\hline Selenium, Se & 0 & 0.0021 & 0.0011 & 0.0021 & 0.001 & 0.0021 & 0 & 0.0021 \\
\hline Bromine, $\mathrm{Br}$ & 0.0021 & 0.0015 & 0.0057 & 0.0015 & 0.0035 & 0.0015 & 0.0024 & 0.0015 \\
\hline Rubidium, Rh & 0.0004 & 0.0011 & 0.0006 & 0.0011 & 0 & 0.0011 & 0 & 0.0011 \\
\hline Strontium, Sr & 0.0031 & 0.002 & 0.0003 & 0.002 & 0 & 0.002 & 0 & 0.002 \\
\hline Yttrium, Y & 0.0008 & 0.0015 & 0.001 & 0.0015 & 0 & 0.0015 & 0.0003 & 0.0015 \\
\hline
\end{tabular}


Table 3. Results of the chemical analysis for selected filters from Tonopah Airport. Chemical components with concentration higher than two times the uncertainty are in bold, while those with concentrations lower than two times the uncertainty are in italics. Concentrations are in $\mu \mathrm{g} / \mathrm{m}^{3}$ (continued).

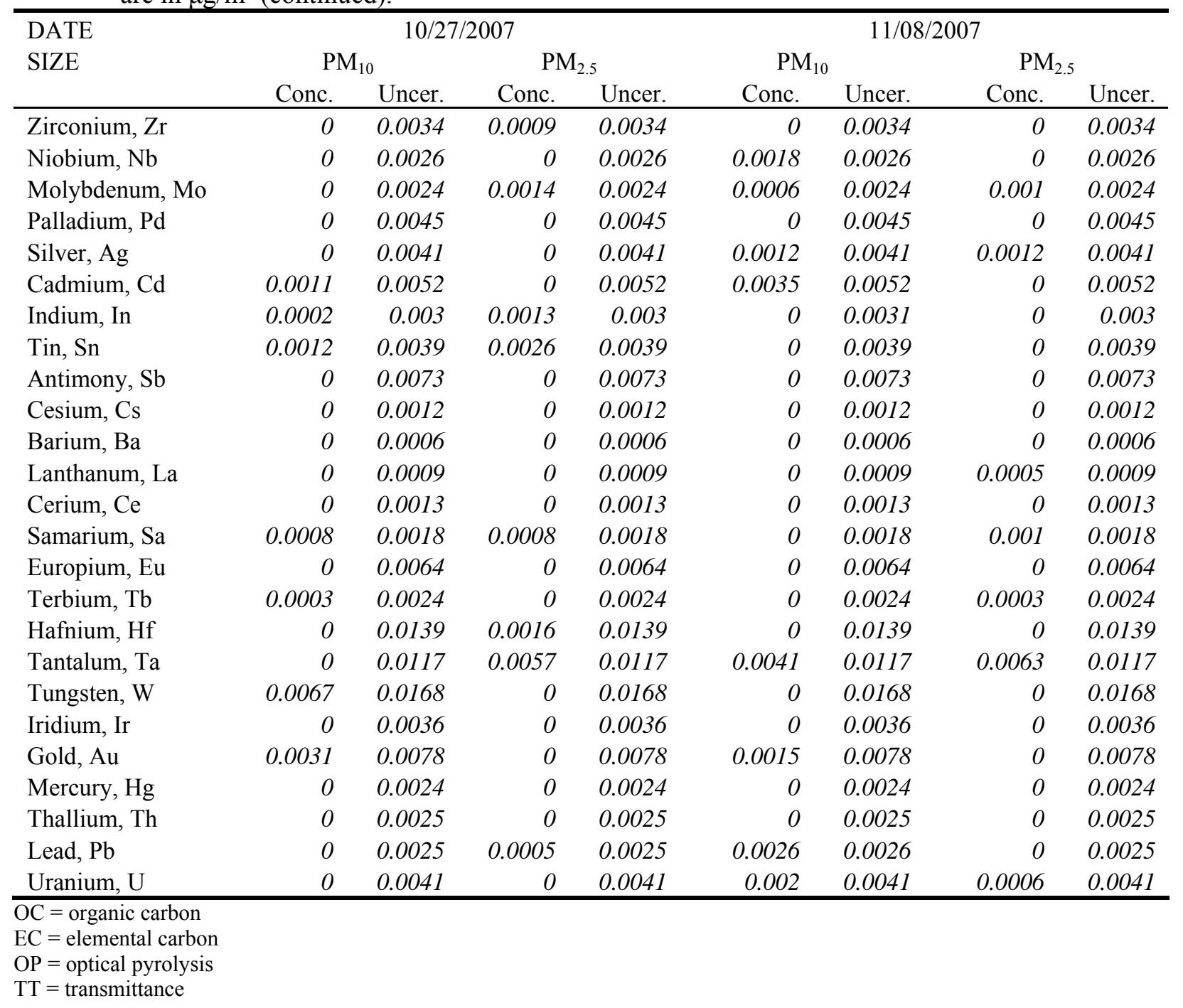

With respect to the chemical composition of $\mathrm{PM}_{10}$ and $\mathrm{PM}_{2.5}$, the following patterns are observed:

- $\quad$ Sulfur $(\mathrm{S})$ was mostly in the form of sulfate $\left(\mathrm{SO}_{4}{ }^{2-}\right)$ with sulfate-to-sulfur ratio of 2.86 to 3.85. Sulfate and ammonium were almost entirely (100\% for sulfate, $100 \%$ for ammonium) associated with fine particles, while 9 to 60 percent of nitrate was measured in $\mathrm{PM}_{2.5}$. Ammonium-to-sulfate molar ratios varied from 1.94 to 2.81, suggesting that sulfate aerosols were mostly in the form of ammonium bisulfate, $\left(\mathrm{NH}_{4}\right) \mathrm{HSO}_{4}$ (Malm et al., 2002). Nitrates appeared to be partially neutralized by ammonium in the fine particle mode, while coarse particles nitrates may be the product of the reactions of nitric acid with soil dust elements such as Ca (Lefer and Talbot, 2001). 
- Carbonaceous aerosol was predominantly in fine particles. For $\mathrm{PM}_{2.5}$, total carbon (OC) concentrations accounted for 26 to 49 percent of particle mass, while very low $\mathrm{EC} / \mathrm{OC}$ ratios were indicative of the absence of combustion-related sources

- Soluble potassium $\left(\mathrm{K}^{+}\right)$accounted for 32 to 70 percent of total potassium in $\mathrm{PM}_{10}$ and for more than 50 percent of total potassium in $\mathrm{PM}_{2.5}$. Soluble potassium is a tracer of biomass burning, which suggested the significant impact of emissions from local and/or regional fire (prescribed or wildfire) events or salts in desert soils. This was further supported by the estimates of nonsoil potassium $\mathrm{K}_{\text {non-soil }}\left(\mathrm{K}_{\text {total }}-(0.26 \mathrm{x}\right.$ [Al] $\left.)\right)$ that were comparable to measured water-soluble $\mathrm{K}^{+}$.

- Ratios of $\mathrm{Al} / \mathrm{Si}$ (0.38 to 0.44$) \mathrm{K} / \mathrm{Fe}$ (1.83 to6.47) were comparable to those determined for samples collected at the Interagency Monitoring of Protected Visibility Environments (IMPROVE) sites in western United States (Al/Si: 0.31 to $0.43, \mathrm{~K} / \mathrm{Fe}: 0.67$ to $0.78, \mathrm{Al} / \mathrm{Ca}: 1.4$ to 1.7$)$ when soil dust was the major component of particulate matter (Kavouras et al., 2005).

The IMPROVE mass estimation scheme is adopted to reconstruct aerosol mass into five major types: sulfate, nitrate, organic, light-absorbing carbon, and soil. For this scheme, sulfate and nitrate are assumed to be in the forms of ammonium sulfate $\left[\left(\mathrm{NH}_{4}\right)_{2} \mathrm{SO}_{4}\right]$ and ammonium nitrate $\left[\mathrm{NH}_{4} \mathrm{NO}_{3}\right]$, respectively (Malm et al., 2004). Organic mass concentration $[\mathrm{OMC}]$ was estimated as $[\mathrm{OMC}]=1.4 \mathrm{x}[\mathrm{OC}]$, where $[\mathrm{OC}]$ is the organic carbon concentration. The 1.4 factor was used to estimate for other elements (mainly hydrogen and oxygen) associated with the composition of organic compounds (White and Roberts, 1977). Soil mass concentration [SOIL] was estimated as the sum of the elements present in the soil as oxides $\left(\mathrm{Al}_{2} \mathrm{O}_{3}, \mathrm{SiO}_{2}, \mathrm{CaO}, \mathrm{K}_{2} \mathrm{O}, \mathrm{FeO}, \mathrm{Fe}_{2} \mathrm{O}_{3}\right.$, and $\left.\mathrm{TiO}_{2}\right)$ as follows:

$[\mathrm{SOIL}]=2.2 \times[\mathrm{Al}]+2.49[\mathrm{Si}]+1.63 \times[\mathrm{Ca}]+2.42 \times[\mathrm{Fe}]+1.94 \times[\mathrm{Ti}]$. Therefore, the reconstructed aerosol mass was estimated as follows:

$$
[\text { Aerosol Mass }]=(128 / 96) \times\left[\mathrm{SO}_{4}\right]+(80 / 62) \times\left[\mathrm{NO}_{3}\right]+\mathrm{EC}+[\mathrm{OMC}]+[\mathrm{SOIL}]
$$

Figure 6 shows the concentrations of ammonium sulfate, ammonium nitrate, organic carbon mass, elemental carbon, and soil for $\mathrm{PM}_{10}$ and $\mathrm{PM}_{2.5}$ collected on October 27, 2007 and November 8, 2007 at the Tonopah Airport. Considering the positive bias for organic carbon measurements:

- Reconstructed particle mass accounted for 73 to 75 percent of measured $\mathrm{PM}_{10}$ mass and for 80 to 98 percent of $\mathrm{PM}_{2.5}$ mass.

- Carbonaceous aerosol (OMC and EC) appeared to account for 11 to 50 percent of $\mathrm{PM}_{10}$ and 36 to 66 percent of $\mathrm{PM}_{2.5}$.

- Soil represented 16 to 28 percent of $\mathrm{PM}_{10}$ and about 6 to 14 percent of $\mathrm{PM}_{2.5}$ mass, while sulfate contributed between 6 and 30 percent on $\mathrm{PM}_{10}$ and 6 to 47 percent on $\mathrm{PM}_{2.5}$ (Figure 6).

- The differences of $\mathrm{PM}_{10}$ and $\mathrm{PM}_{2.5}$ fractions are due to higher concentration of soil elements in the coarse fraction (particles with diameter between 2.5 and $10 \mu \mathrm{m}$ ). Higher $\mathrm{PM}_{2.5}$ mass concentrations for October 27, 2007, may be attributed to increased concentrations of organic carbon associated with smoke from wildfires in southern California (San Diego area). 


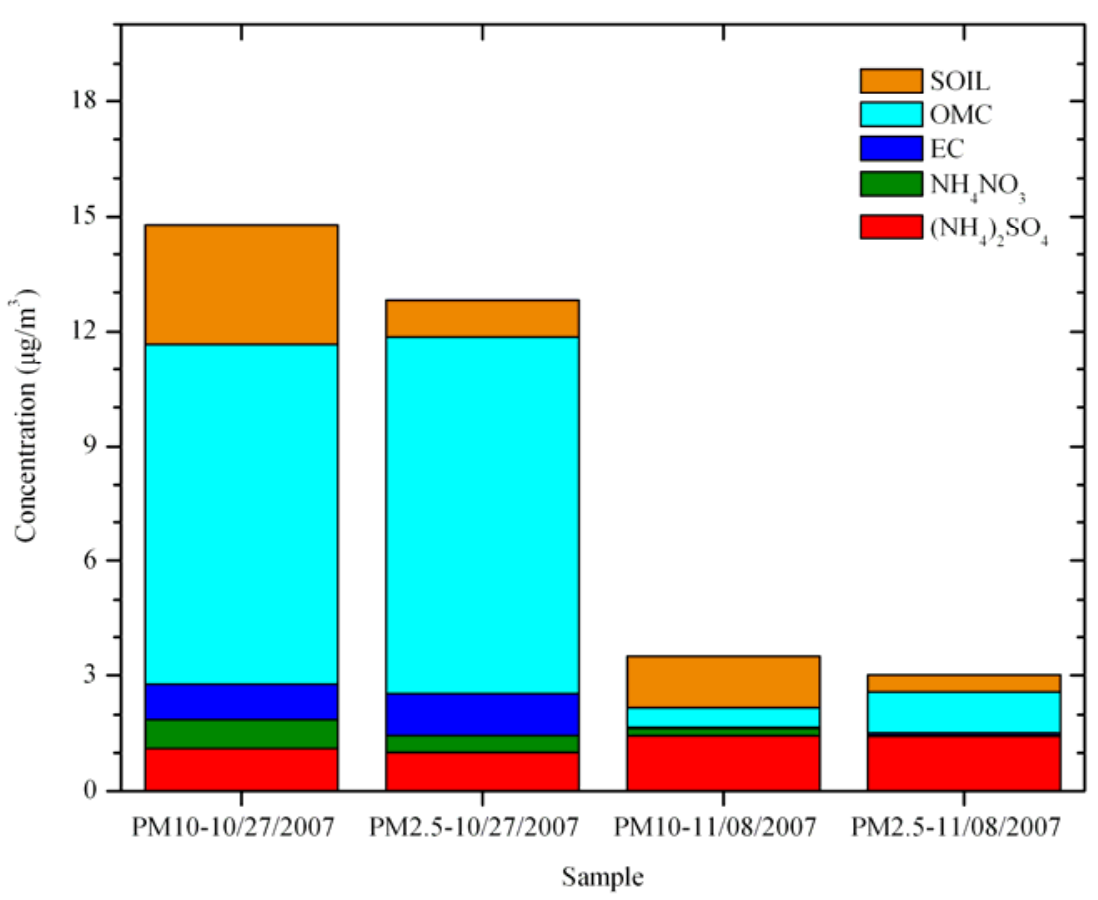

Figure 6. Reconstructed mass for $\mathrm{PM}_{10}$ and $\mathrm{PM}_{2.5}$ based on chemical composition.

\section{Aerosol Monitoring}

\section{Monitor Description and Procedures}

The TEOM Series 1400 Ambient Particulate Monitor from Thermo Scientific and the DUSTTRAK ${ }^{\mathrm{TM}}$ Aerosol Monitor from TSI were used to continuously measure $\mathrm{PM}_{10}$ and $\mathrm{PM}_{2.5}$ mass concentrations (Figure 7). The TEOM Series 1400 monitors the ambient particulate mass concentration of $\mathrm{PM}_{10}$ (EPA certification EQPM-1090-079) (or $\mathrm{PM}_{2.5}$ ) in real time by direct measurement of particulate mass collected on a filter attached to an oscillating inertial mass transducer. The mass transducer in the sensor unit has a tapered ceramic tube (element) that is fixed at the downstream end and a Teflon-coated glass fiber filter on the free end. The oscillating frequency of the tube changes proportionally as ambient air is drawn through the filter and the particulate loading thereon increases. The flow rate through the filter sample is set at a nominal 3.0 liters $/ \mathrm{min}$. A bypass (auxiliary) flow provides an additional 13.67 liters/min for a total flow rate of 16.67 liters $/ \mathrm{min}$. An internal datalogger stores mass values, time, and some meteorological data. To eliminate bias caused by humidity, the filter is heated to $50^{\circ} \mathrm{C}$. Operation, calibration, and maintenance of the TEOM are described in SOP DRI 4.111-2 "RUPPRECHT \& PATASHNICK (R\&P), SERIES 1400A TAPERED ELEMENT OSCILLATING MICROBALANCE (TEOM)." Flow calibration and leak tests were performed on the day of installation (September 27, 2007). Data were downloaded during site visits. Regular checks of time, filter loading, by-pass filter, and flow rates were accomplished during site visits. 

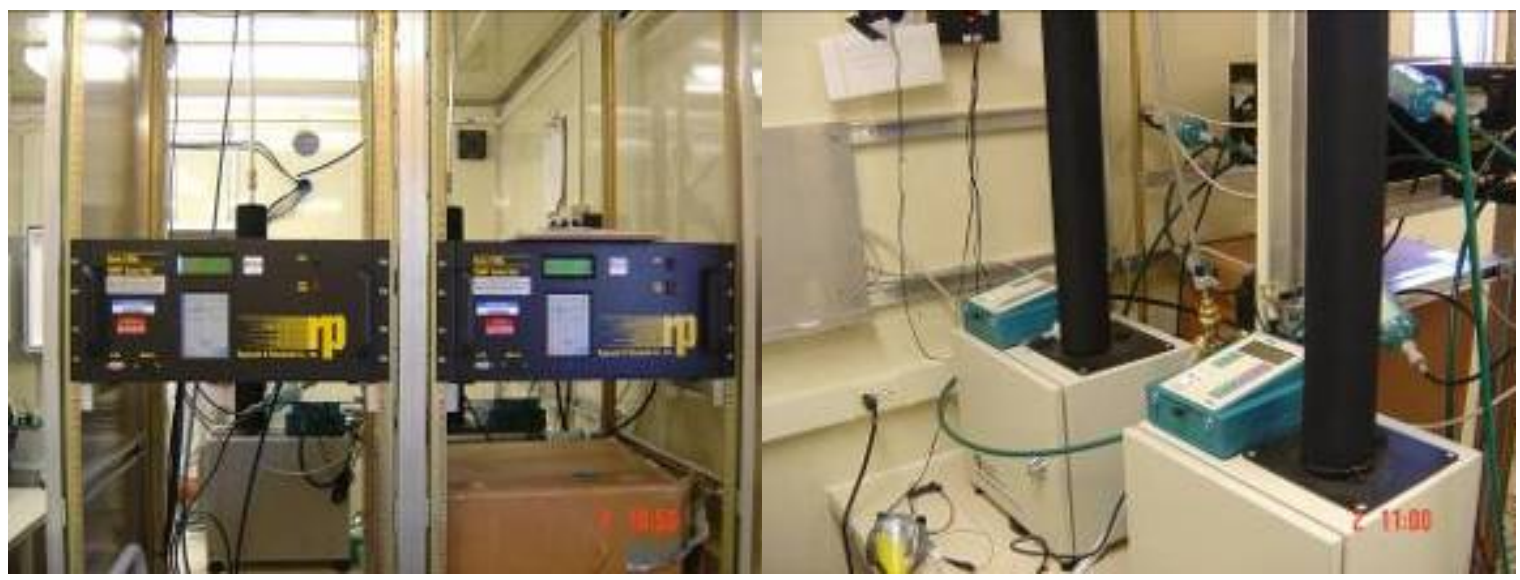

Figure 7. Left photograph: The front panels of $\mathrm{PM}_{10}$ (right on the left photograph) and $\mathrm{PM}_{2.5}$ (left on the left photograph) of TEOM. Right photograph: The DustTrak monitors (green) resting on top of the two TEOM measuring units.

The DUSTTRAK ${ }^{\mathrm{TM}}$ Aerosol Monitors are portable, battery operated laser photometers that provide measurements of particle mass based on $90^{\circ}$ light scattering. Atmospheric aerosol passes through a size selective inlet (either $\mathrm{PM}_{10}$ or $\mathrm{PM}_{2.5}$ ) and is directed to an optics chamber at a flow rate of 1.7 liters $/ \mathrm{min}$. The light source is a laser diode that emits light at a wavelength of $780 \mathrm{~nm}$. The aerosol sample is drawn into the sensing chamber where it is illuminated with a narrow beam of laser light. Light scattered by aerosol particles is collected by a set of lenses and focused onto the photodetector. The detector signal is proportional to the amount of scattered light, which is proportional to the mass concentration of the aerosol. Voltage is read by the processor and multiplied by an internal calibration constant to yield mass concentration. The calibration constant is pre-set by the manufacturer for scattering characteristics of the respirable mass of ISO 12103-1, Al test dust. Local variations in aerosol particle size distribution and composition relative to this standard may result in differences in the actual response factor of the instrument. The operation, calibration, and maintenance of the DUSTTRAK are described in SOP DRI 2.112-2 “TSI INCORPORATED MODEL 8520 DUSTTRAK AEROSOL MONITOR FOR THE YUCCA MOUNTAIN AIR QUALITY PROGRAM.”

Both $\mathrm{PM}_{10}$ and $\mathrm{PM}_{2.5}$ DUSTTRAK inlets were attached on a wide "Y" connector, which was connected to one end of a second "Y" (Figure 8). A funnel was connected to the other end of the second "Y" to achieve fast exchange of ambient air into the sampling line. Flow calibration and zero-test were performed on the day of installation (August 29, 2007) and subsequent site visits. Deviations in flow were predominantly due to failure of the pump diaphragm. In those cases, the instrument was replaced. Deviations of the zero check were corrected by performing zero calibration according to the manufacturer's operational instruction manual. 


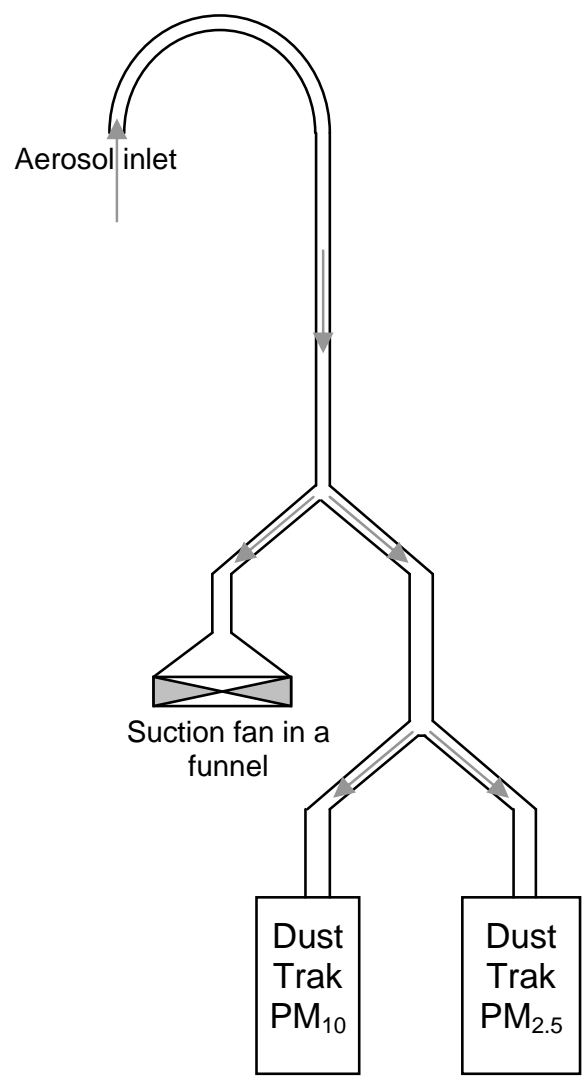

Figure 8. Schematic drawing of the sampling inlet for DUSTTRAK (not to scale).

\section{Continuous Measurements of $\mathrm{PM}_{10}$ and $\mathrm{PM}_{2.5}$}

Trends and correlations of particle mass are examined using hourly TEOM data integrated for 24 hours (from 0:00. to 23:00). Statistics of 24-h particle mass are presented in Table Error! Reference source not found.4.

Table 4. Statistics for 24-h $\mathrm{PM}_{10}$ and $\mathrm{PM}_{2.5}$ TEOM mass concentrations.

\begin{tabular}{rrrrcc}
\hline & Mean & Median & Minimum & Maximum & Std. Deviation \\
\hline $\mathrm{PM}_{10}$ & 7.6 & 6.4 & 3.2 & 33.1 & 4.8 \\
$\mathrm{PM}_{2.5}$ & 1.7 & 1.0 & 0.0 & 15.3 & 2.1 \\
\hline
\end{tabular}

Twenty-four-h $\mathrm{PM}_{10}$ levels ranged from 3.2 to $33.1 \mu \mathrm{g} / \mathrm{m}^{3}$, with a mean of $7.6(\sigma=4.8)$ $\mu \mathrm{g} / \mathrm{m}^{3}$, while $\mathrm{PM}_{2.5}$ concentrations varied from 0.0 to $15.3 \mu \mathrm{g} / \mathrm{m}^{3}$, with a mean of $1.7(\sigma=2.1)$ $\mu \mathrm{g} / \mathrm{m}^{3}$. Similar temporal trends were found for $\mathrm{PM}_{10}$ and $\mathrm{PM}_{2.5}$ at Tonopah Airport. A high $\mathrm{PM}_{10}$ episode on October 26 through 28, 2007, was observed, with $\mathrm{PM}_{2.5}$ mass concentration of approximately $9 \mu \mathrm{g} / \mathrm{m}^{3}$ (Figure 9). Fine particles accounted for only 20 percent of $\mathrm{PM}_{10}$ mass $\left(\mathrm{PM}_{2.5} / \mathrm{PM}_{10}\right.$ ratio of 0.20$)$ (Figure 10). While differences in particle mass for weekdays/weekends were not statistically significant, somewhat higher $\mathrm{PM}_{10}$ levels were measured on Saturday (Day \#6) (Figure 11). 


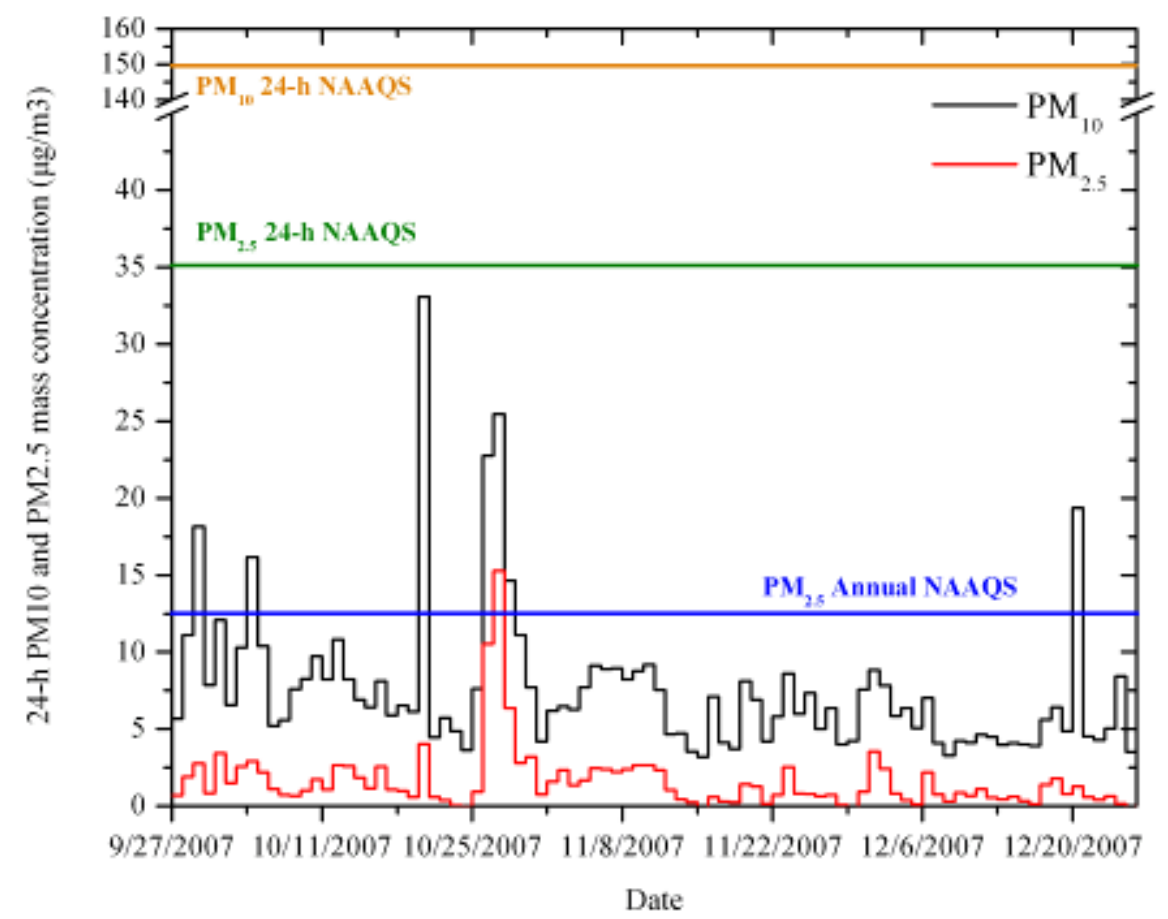

Figure 9. Mean 24-h $\mathrm{PM}_{10}$ and $\mathrm{PM}_{2.5}$ mass concentrations measured by TEOM at Site \#8 (Tonopah Airport).

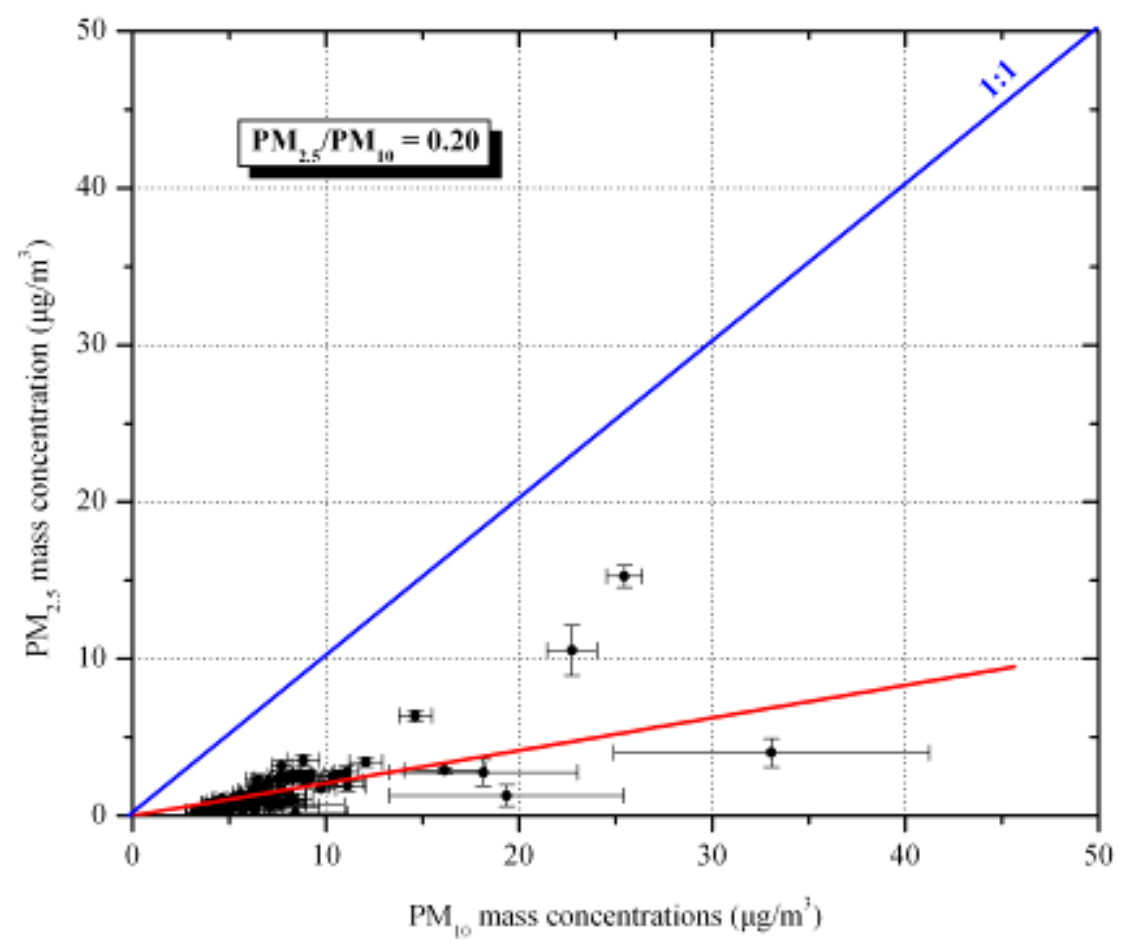

Figure 10. $\mathrm{PM}_{2.5} / \mathrm{PM}_{10}$ mass ratios measured by TEOM at Site \#8 (Tonopah Airport). Error bars represent the standard error of the mean. 


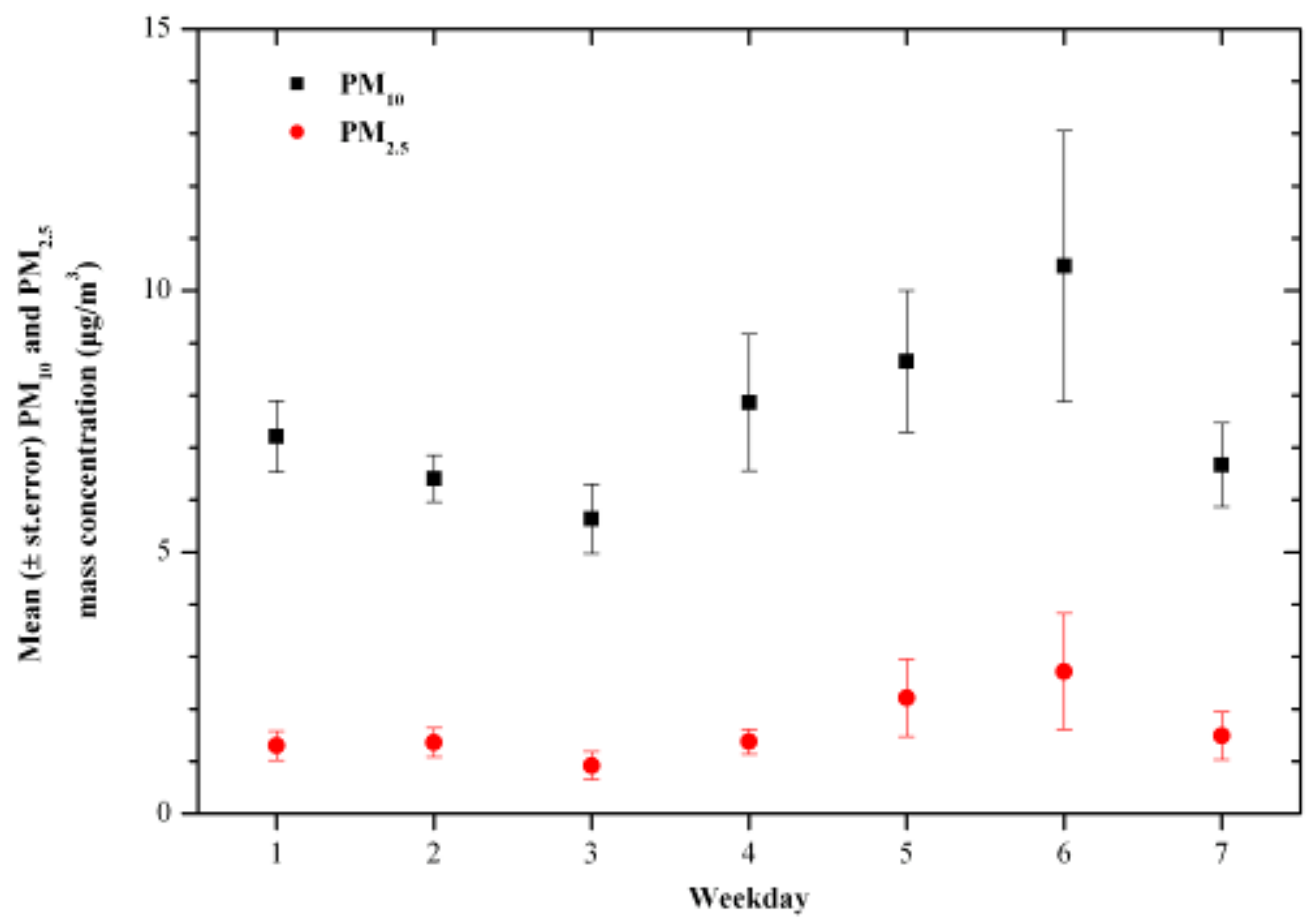

Figure 11. Variation of mean ( \pm st.error) $\mathrm{PM}_{10}$ and $\mathrm{PM}_{2.5}\left(\mu \mathrm{g} / \mathrm{m}^{3}\right)$ in weekdays and weekends at Site \#8 (Tonopah Airport) (Monday=1, Tuesday=2, Wednesday=3, Thursday=4, Friday=5, Saturday $=6$, Sunday $=7$ ).

Variations of daily $\mathrm{PM}_{10}$ and $\mathrm{PM}_{2.5}$ measured with DUSTTRAK and TEOM are presented in Figure 12 and Figure 13. The absolute differences between concentrations measured by DUSTTRAK and TEOM were larger for $\mathrm{PM}_{10}$ as compared to those for $\mathrm{PM}_{2.5}$. Daily trends of particle mass concentrations measured by DUSTTRAK and TEOM were comparable for $\mathrm{PM}_{2.5}$ mass. The time series plots for $\mathrm{PM}_{10}$ particle mass concentrations measured by TEOM and DUSTTRAK are somewhat comparable in shape and almost identical for $\mathrm{PM}_{2.5}$. The temporal correlations between DUSTTRAK and TEOM were low to moderate $(\mathrm{R}=0.32$ to 0.70$)$. A slope of 9.0980 and an intercept of $-22.14122 \mu \mathrm{g} / \mathrm{m}^{3}$ (Figure 14) were computed for $\mathrm{PM}_{10}$. This was indicative of the weakness of the lightscattering technique to monitor dust particles that represented more than 80 percent of $\mathrm{PM}_{10}$ mass at the Tonopah Airport at very low concentration levels. As for $\mathrm{PM}_{2.5}$, the slope between TEOM and DUSTTRAK PM 2.5 was 2.54327, with a rather low intercept of $-0.9549 \mu \mathrm{g} / \mathrm{m}^{3}$. This agreement was due to the fact that light scattering provides more reliable measurements of particle mass in the accumulation mode. 


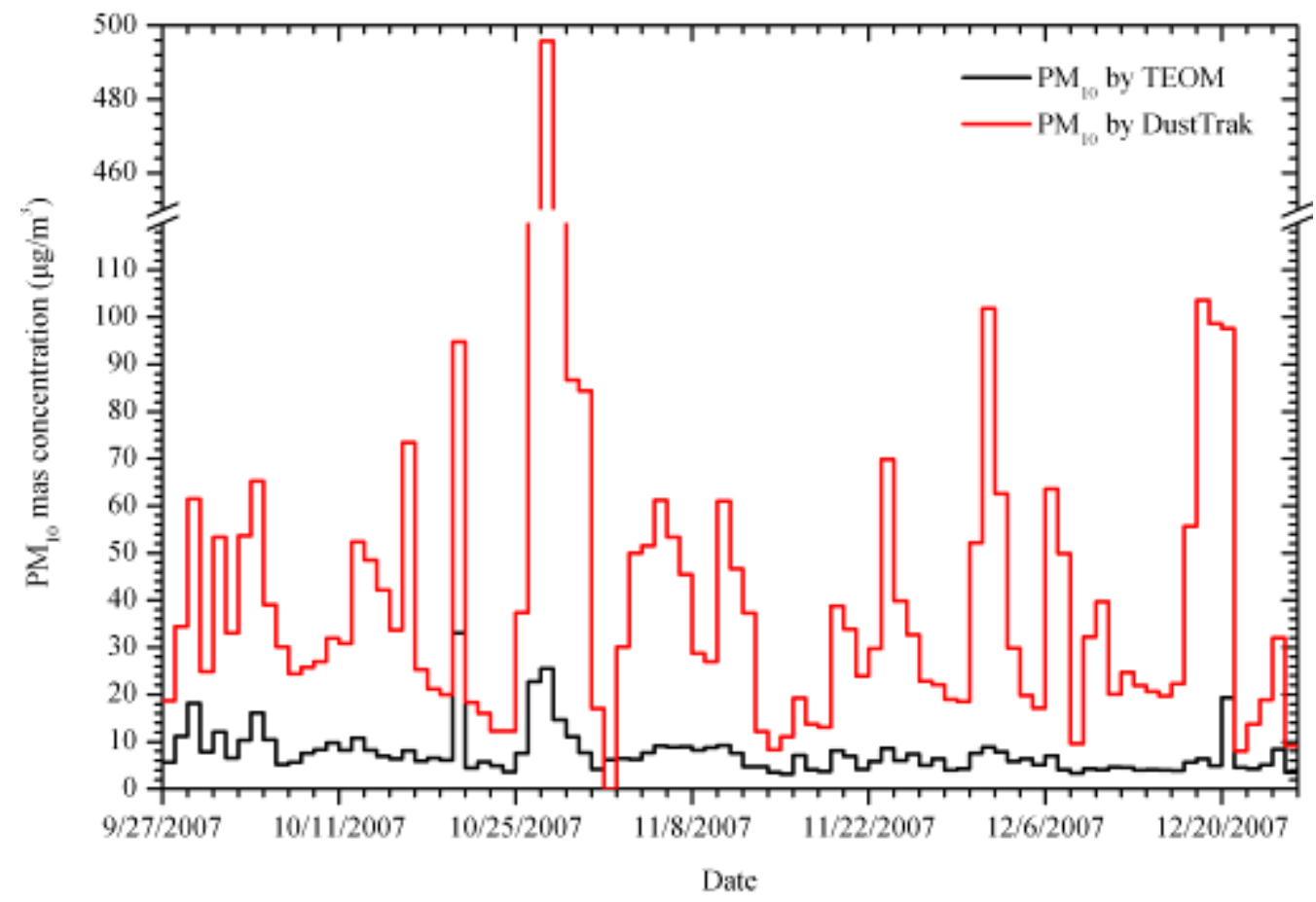

Figure 12. $\mathrm{PM}_{10}$ mass $\left(\mu \mathrm{g} / \mathrm{m}^{3}\right)$ measured with DUSTTRAK and TEOM at Site \#8 (Tonopah Airport).

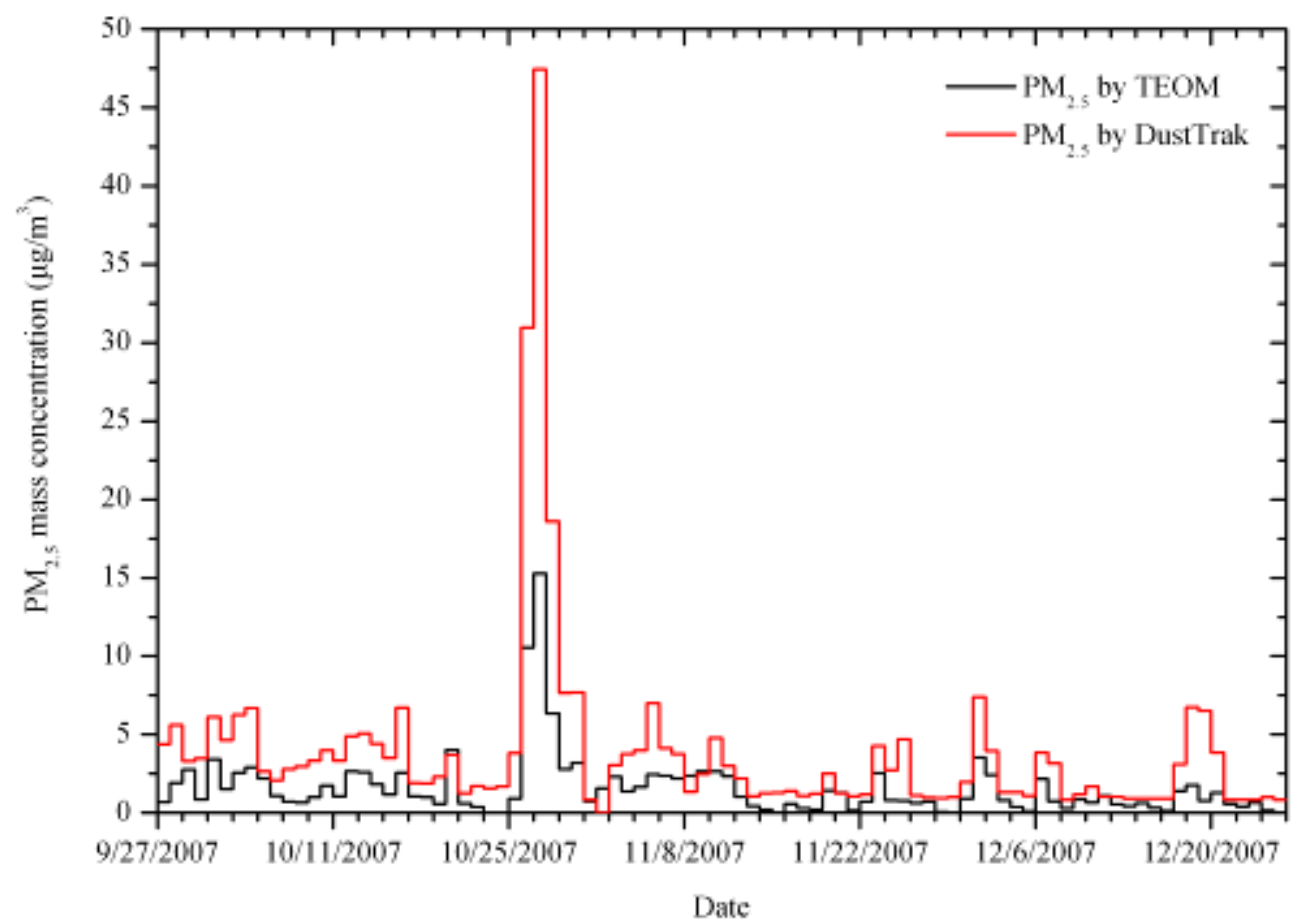

Figure 13. $\mathrm{PM}_{2.5}$ mass $\left(\mu \mathrm{g} / \mathrm{m}^{3}\right)$ measured with DUSTTRAK and TEOM at Site \#8 (Tonopah Airport). 


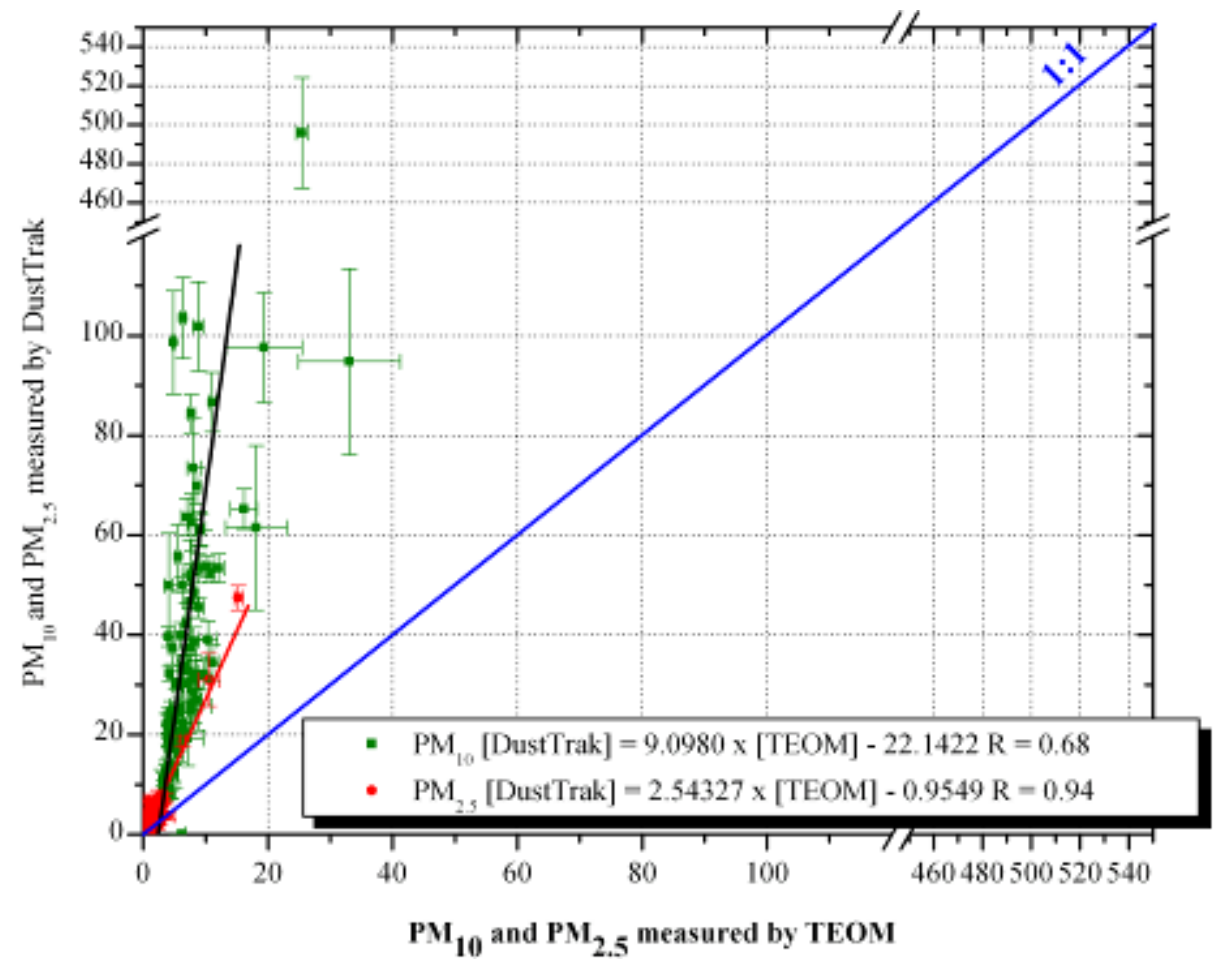

Figure 14. Comparison of 24-h $\mathrm{PM}_{10}$ and $\mathrm{PM}_{2.5}$ mass concentrations measured by TEOM and DUSTTRAK. Error bars represent the standard error of the mean.

\section{Comparison of Filter to Continuous Results}

Figure 15 and Figure 16 show the relationships between $\mathrm{PM}_{10}$ and $\mathrm{PM}_{2.5}$ measured by TEOM/DUSTTRAK and FRM filter-based methods. The temporal correlations between $\mathrm{PM}_{10}$ and $\mathrm{PM}_{2.5}$ measurements by TEOM and filter methods were good, with correlation coefficients from 0.94 to 0.97 . The slopes for $\mathrm{PM}_{10}$ and $\mathrm{PM}_{2.5}$ measured by TEOM and filters were 1.0533 and 0.93851 , respectively, with intercepts of 3.22741 and -0.22317 . The agreement between DUSTTRAK and filter-based $\mathrm{PM}_{10}$ and $\mathrm{PM}_{2.5}$ measurements was quite poor $(\mathrm{R}=0.15$ to 0.35$)$, with a slope of 1.9957 for $\mathrm{PM}_{10}$ and 0.25695 for $\mathrm{PM}_{2.5}$, while high intercepts are computed. 


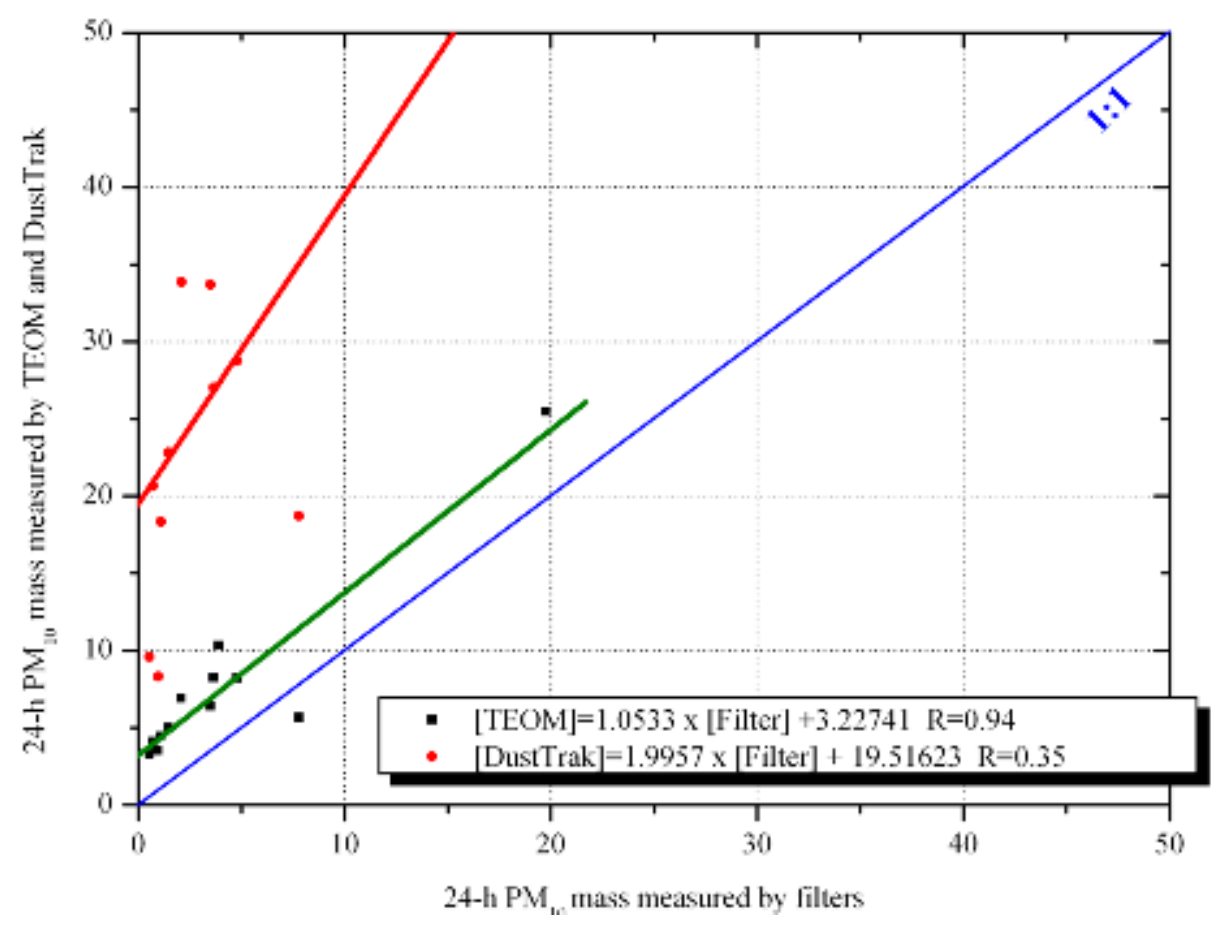

Figure 15. Relationships between $\mathrm{PM}_{10}$ concentrations $\left(\mu \mathrm{g} / \mathrm{m}^{3}\right)$ measured by TEOM, DUSTTRAK, and filter-based methods.

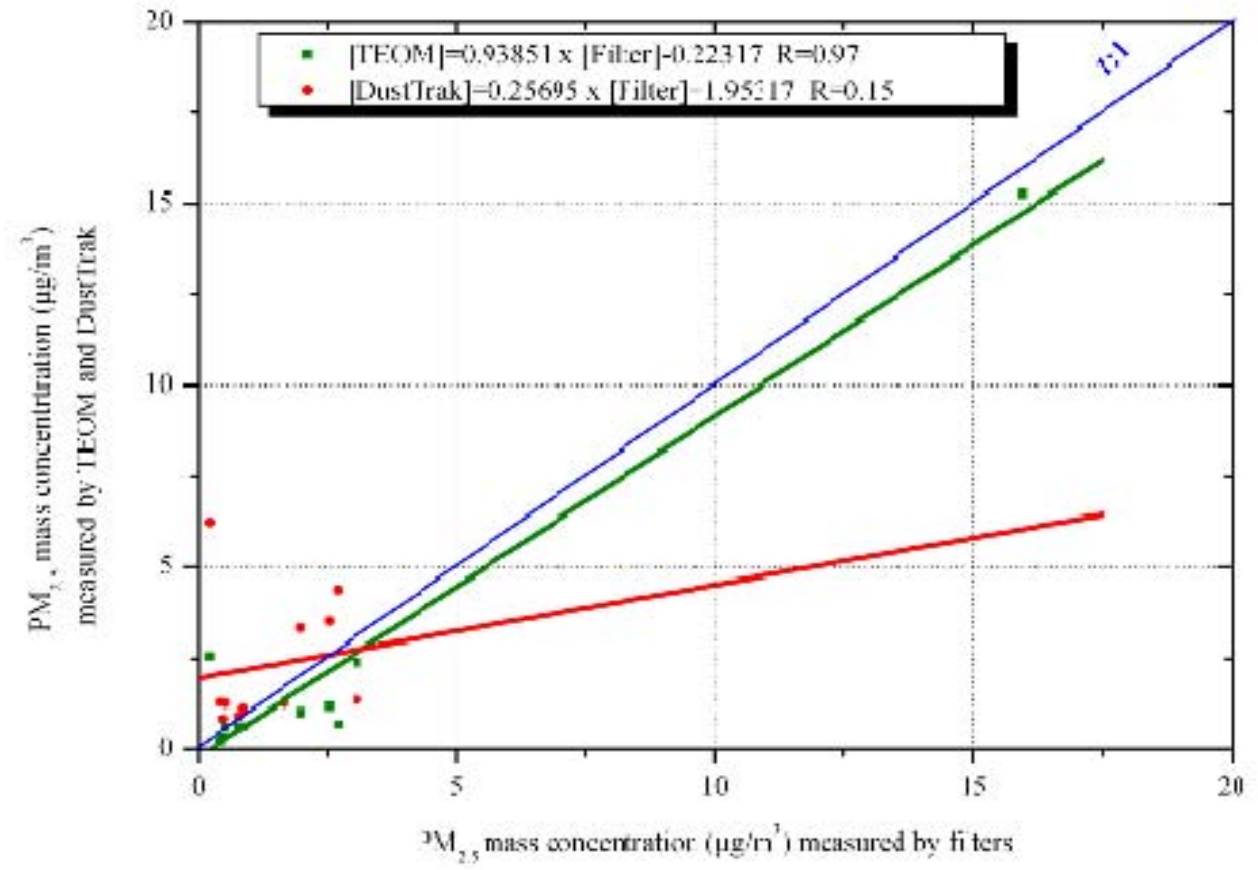

Figure 16. Relationships between $\mathrm{PM}_{2.5}$ concentrations $\left(\mu \mathrm{g} / \mathrm{m}^{3}\right)$ measured by TEOM, DUSTTRAK, and filter-based methods. 


\section{METEOROLOGY}

Variations of hourly data for each meteorological parameter are presented in Figure 17 through Figure 21. Descriptive statistics of hourly data also are presented in Table 5. Solar radiation progressively increased up to 76.7 watts $/ \mathrm{m}^{2}$ (Figure 17). Ambient temperature varied from 11.3 to $93.3^{\circ} \mathrm{F}$, with a mean temperature of $48.0^{\circ} \mathrm{F}$ for the monitoring period (Table 5; Figure 18). Four rainfall events adding up $2.06 \mathrm{~mm}$ were recorded (Figure 19).

Table 5. Descriptive statistics of 1-hour meteorological data.

\begin{tabular}{lrccc}
\hline & Mean & Minimum & Maximum & Sum \\
\hline Solar radiation $\left(\right.$ watts $\left./ \mathrm{m}^{2}\right)$ & 14.5 & 0.0 & 76.7 & \\
Wind speed $(\mathrm{miles} / \mathrm{h})$ & 8.9 & 0.1 & 33.6 & \\
Temperature $\left({ }^{\circ} \mathrm{F}\right)$ & 48.0 & 11.3 & 93.3 & \\
Relative humidity $(\%)$ & 40.2 & 4.0 & 97.5 & \\
Precipitation $(\mathrm{mm})$ & & & & 2.06 \\
\hline
\end{tabular}

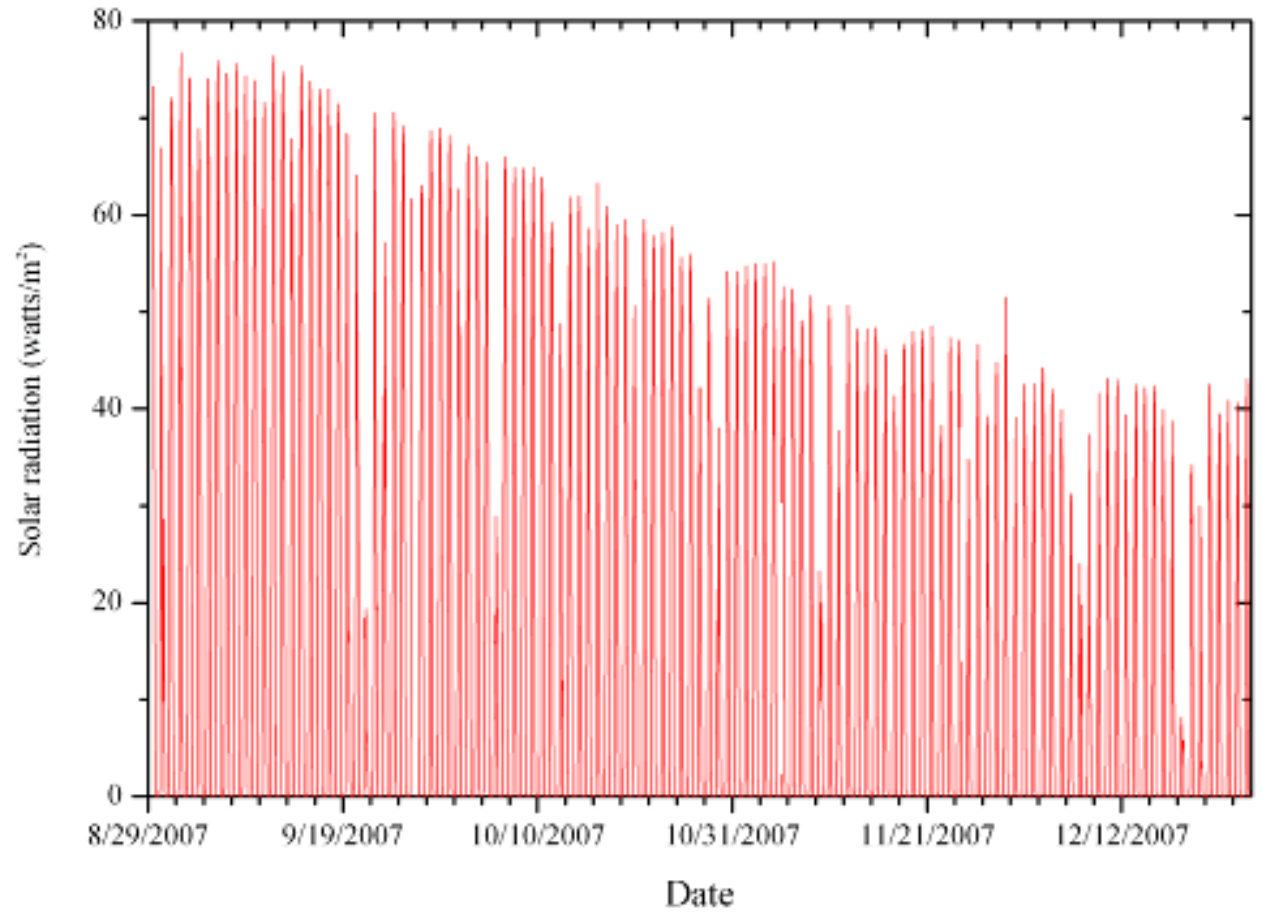

Figure 17. Solar radiation (in watts $/ \mathrm{m}^{2}$ ) at Site $\# 8$ (Tonopah Airport). 


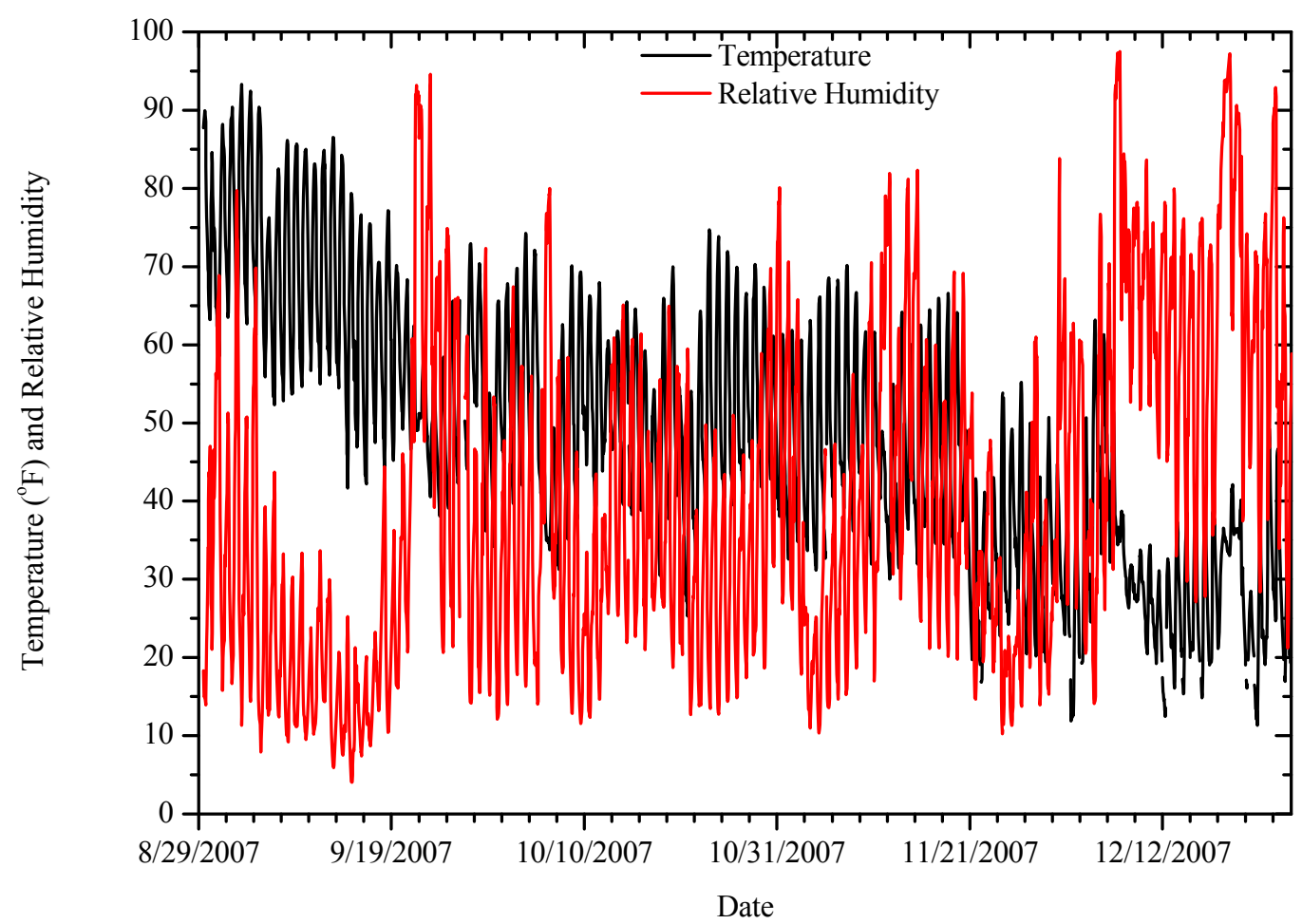

Figure 18. Temperature (in ${ }^{\circ} \mathrm{F}$ ) and relative humidity at Site \#8 (Tonopah Airport).

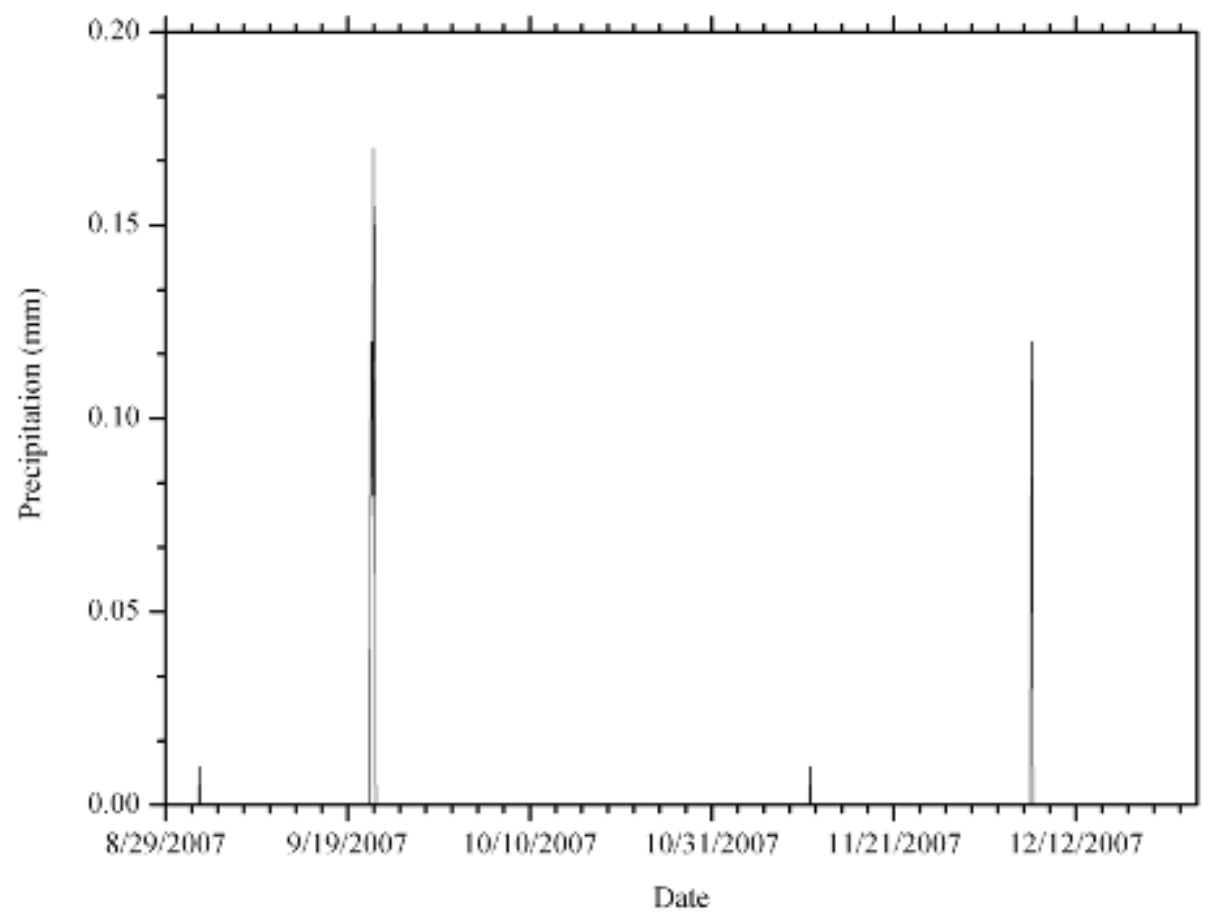

Figure 19. Total precipitation (in $\mathrm{mm}$ ) at Site \#8 (Tonopah Airport). 


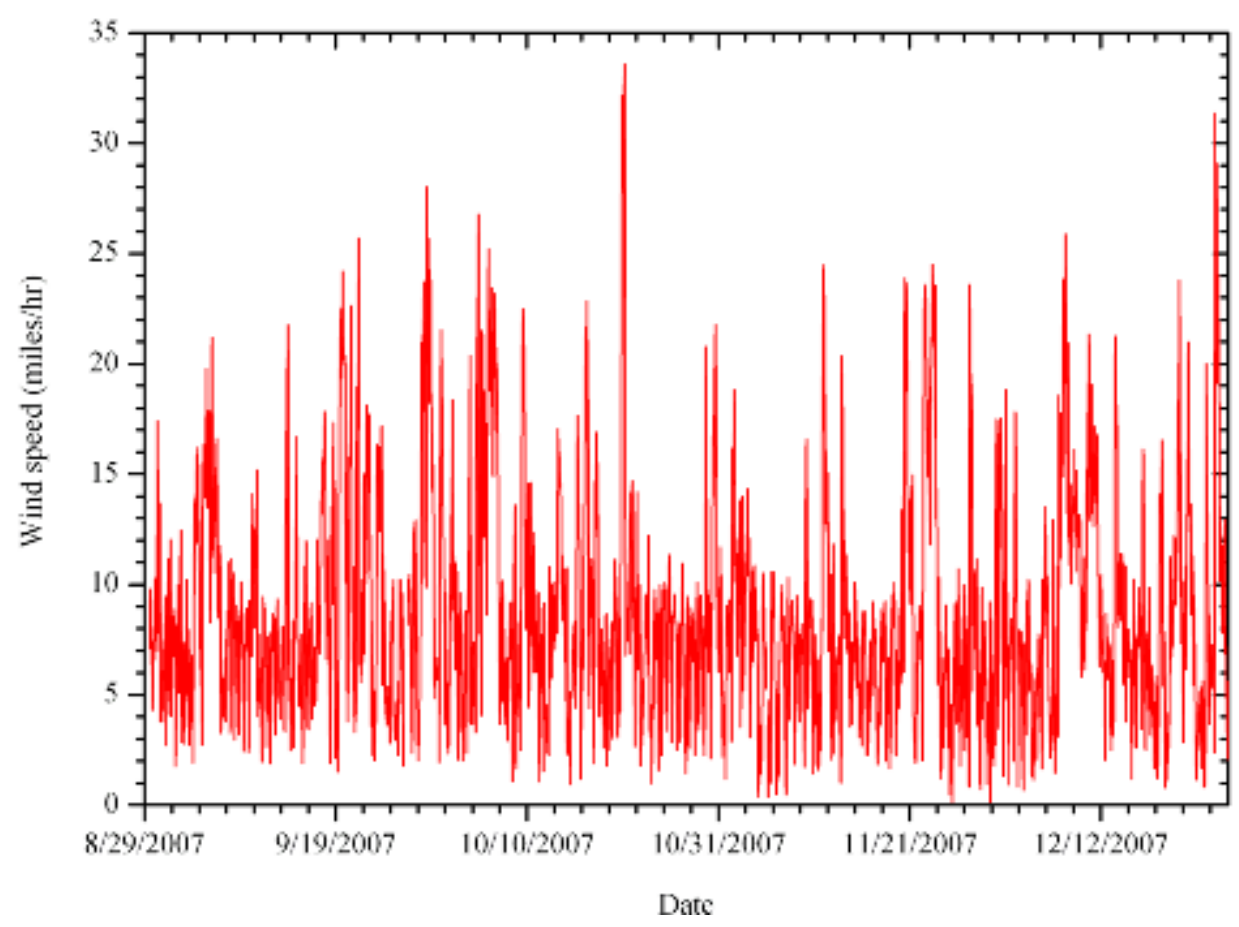

Figure 20. Wind speed (in miles/hr) at Site \#8 (Tonopah Airport).

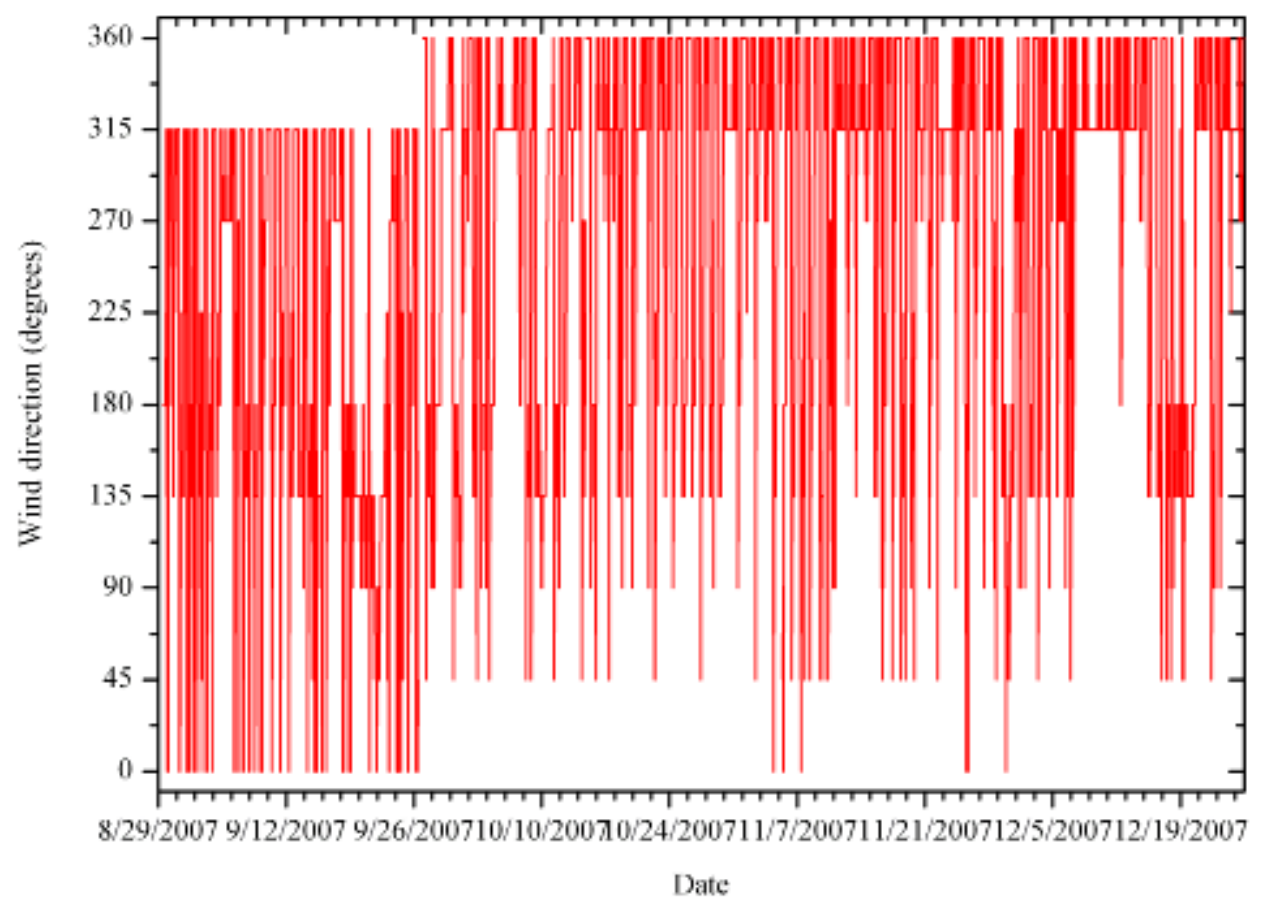

Figure 21. Wind direction at Site \#8 (Tonopah Airport). 
Wind conditions for the monitoring period were described by north/northwest winds during the night and southeast winds during the day, with wind speeds mostly in the range of 5 to 15 miles/hour (Figure 20 and Figure 21). The classification of wind conditions was retrieved from the Federal Meteorological Handbook (Table 6). The mean wind speed for each direction bin ( 8 bins) is presented in Figure 22.

Table 6. Wind condition classifications.

\begin{tabular}{cl}
\hline Miles/hour & Specification \\
\hline$<1$ & Calm; smoke rises vertically. \\
1 to 5 & $\begin{array}{l}\text { Direction of wind shown by smoke drift not by wind vanes. Wind felt on face; leaves } \\
\text { rustle; vanes moved by wind. }\end{array}$ \\
5 to 9 & Leaves and small twigs in constant motion; wind extends light flag. \\
9 to 14 & Raises dust, loose paper; small branches moved. \\
14 to 23 & $\begin{array}{l}\text { Small trees in leaf begin to sway; crested wavelets form on inland waters. Large branches } \\
\text { in motion; whistling heard in overhead wires; umbrellas used with difficulty. }\end{array}$ \\
23 to 35 & $\begin{array}{l}\text { Whole trees in motion; inconvenience felt walking against wind. Breaks twigs off trees; } \\
\text { impedes progress. }\end{array}$ \\
35 to 48 & Slight structural damage occurs. Trees uprooted; considerable damage occurs. \\
$>48$ & Widespread damage.
\end{tabular}

(retrieved from Federal Meteorological Handbook; Chapter 5. Wind;

http://www.nws.noaa.gov/oso/oso1/oso12/fmh1/fmh1ch5.htm\#chp5link)

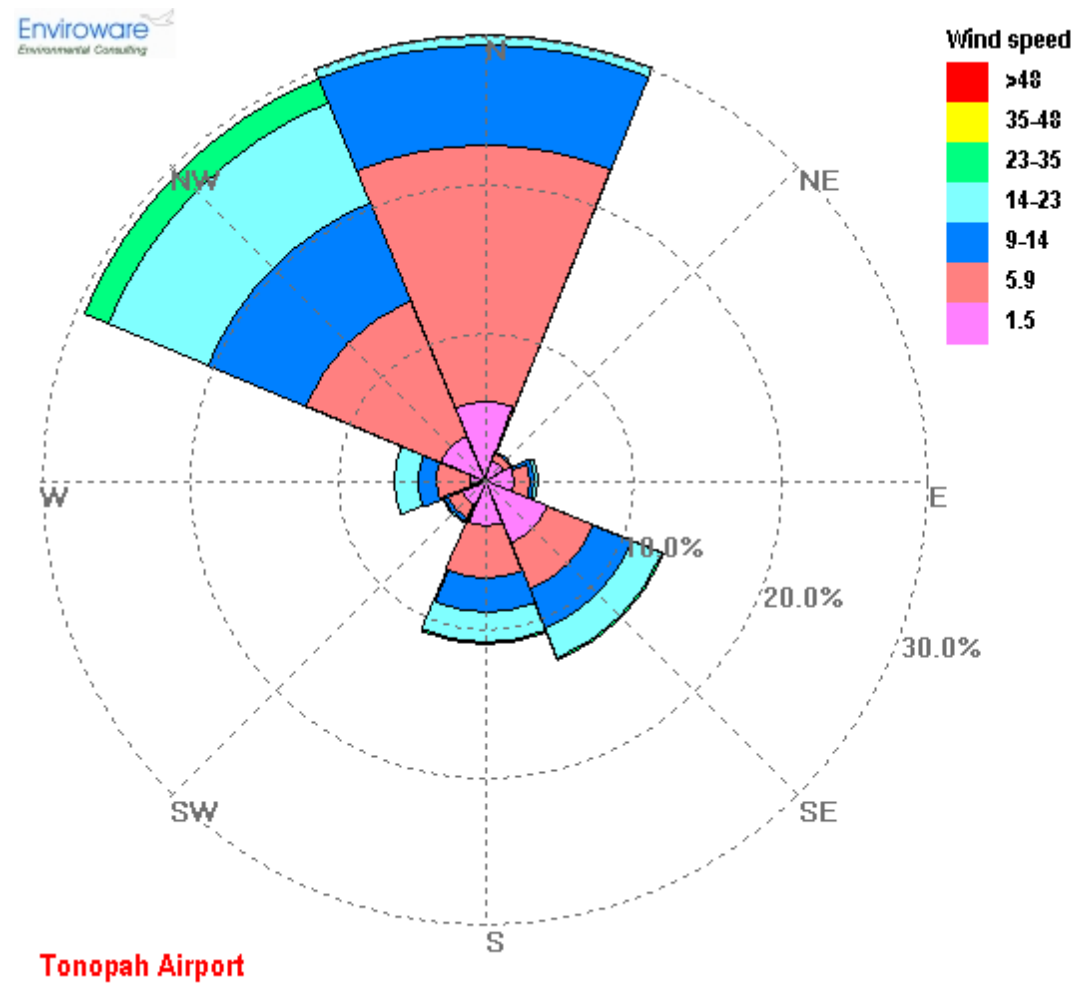

Figure 22. Wind direction and speed at Tonopah Airport. 
For the entire monitoring period, winds were blowing from the north and northwest. Less than 3 percent of southeast winds were associated with wind speeds higher than 14 miles/hour, with a mean wind speed of 8.9 miles/hour. This is partly controlled by the topography of the region. Lower wind speeds are recorded for winds blowing from the northeast (mean wind speed of 3 miles/hour) (Figure 23).

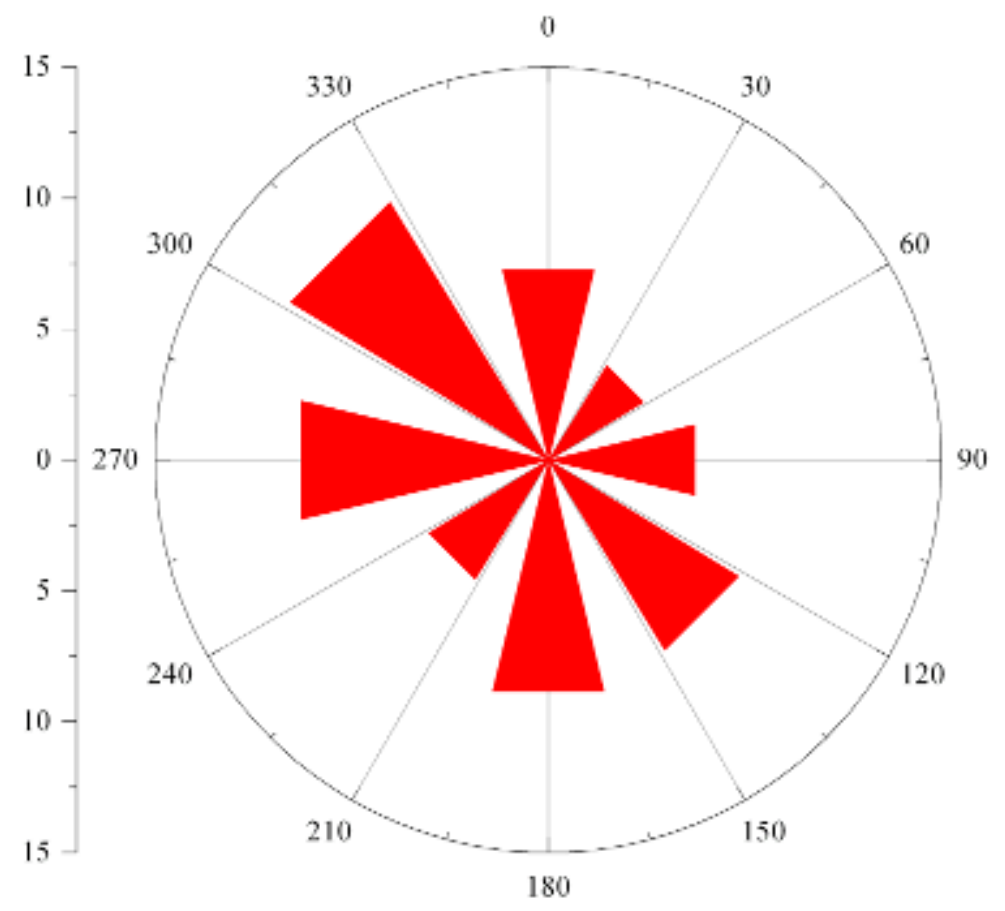

Figure 23. Average wind speed for each wind direction sector. Error bars represent the standard error of the mean.

\section{Relationships of Meteorology with Aerosol Measurements}

Trends and correlations of PM mass with meteorological conditions are shown for hourly TEOM data. The increase in wind speed triggered higher $\mathrm{PM}_{10}$ concentrations but a gradual decrease on $\mathrm{PM}_{2.5}$ concentrations. A rather bimodal pattern is observed for both fractions of particle mass (Figure 24). The first mode is associated with comparatively higher particle mass concentration in early morning (5:00 to 6:00) followed by a gradual decrease. A second, less pronounced mode can be observed in late afternoon (18:00 to 20:00), especially for the fine fraction. There are no significant differences of $\mathrm{PM}_{2.5}$ concentrations for different wind directions, while somewhat higher $\mathrm{PM}_{10}$ levels were recorded for southerly winds as compared to those blowing from the north (Figure 25 and Figure 26). 


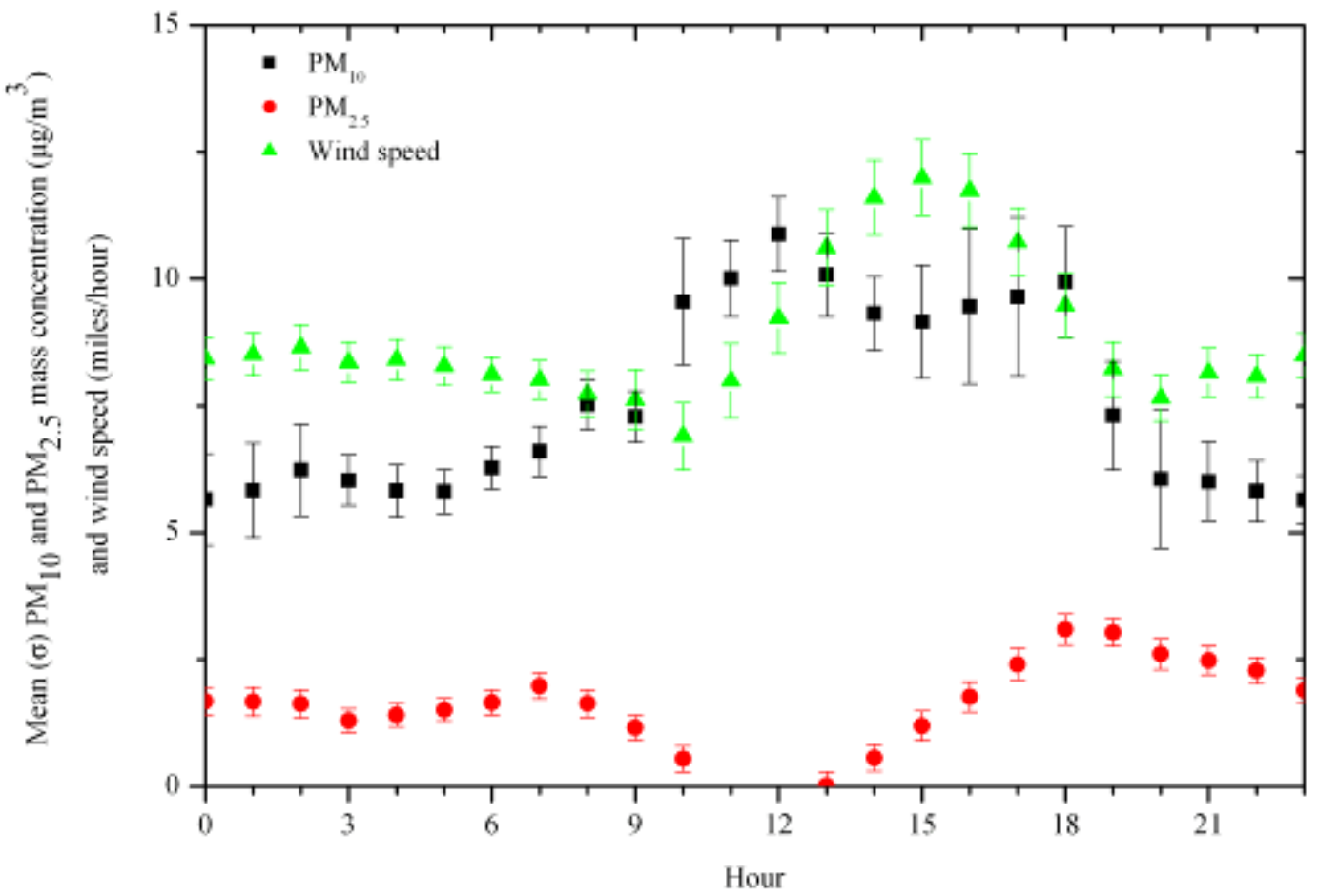

Figure 24. Hourly variation of $\mathrm{PM}_{10}$ and $\mathrm{PM}_{2.5}$ mass concentrations $\left(\mu \mathrm{g} / \mathrm{m}^{3}\right)$ as well as wind speed (miles/hour) at Site \#8 (Tonopah Airport). Error bars represent the standard error of the mean.

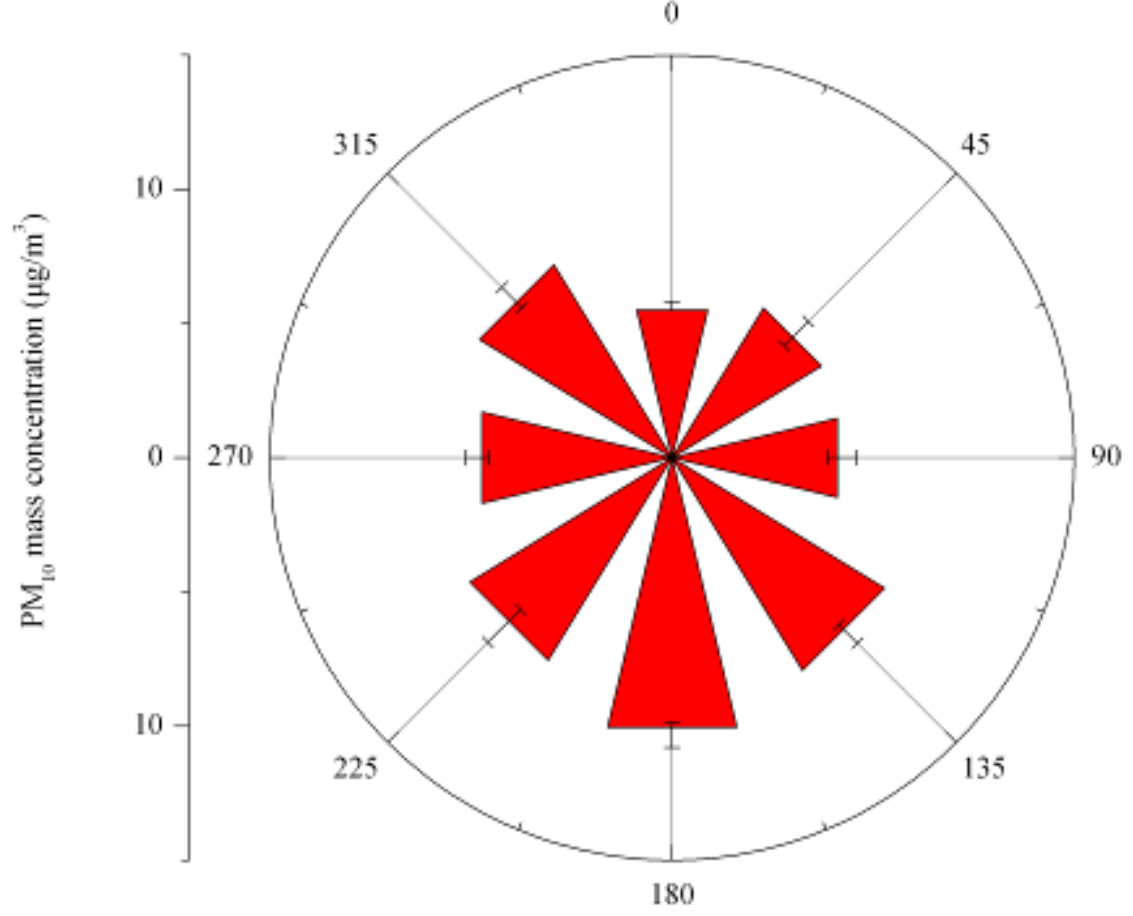

Figure 25. Mean ( \pm st.error) of $\mathrm{PM}_{10}$ mass concentrations $\left(\mu \mathrm{g} / \mathrm{m}^{3}\right)$ for different wind direction sectors at Site \#8 (Tonopah Airport). 


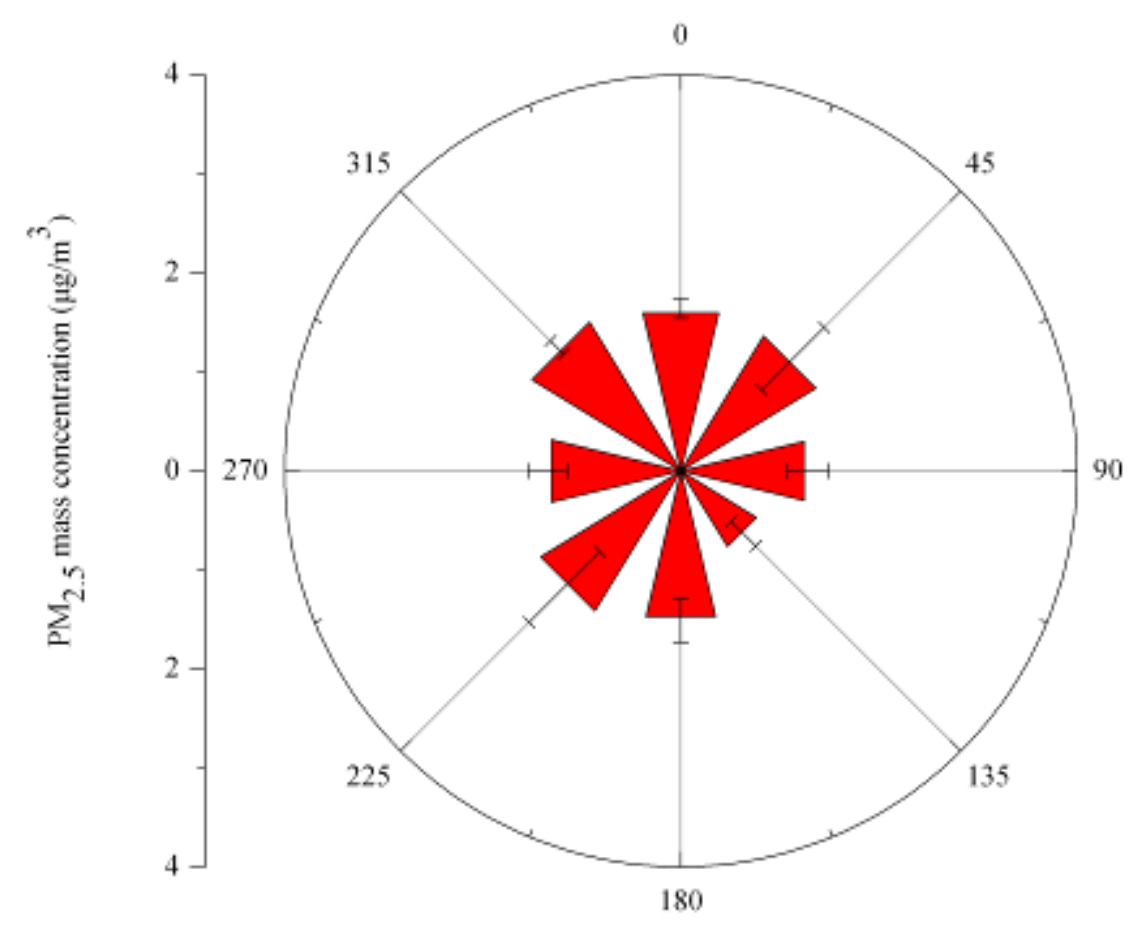

Figure 26. Mean ( \pm st.error) of $\mathrm{PM}_{2.5}$ mass concentrations $\left(\mu \mathrm{g} / \mathrm{m}^{3}\right)$ for different wind direction sectors at Site \#8 (Tonopah Airport).

\section{CONCLUSIONS}

$\mathrm{PM}_{10}$ and $\mathrm{PM}_{2.5}$ mass concentrations and meteorological conditions were monitored at the Tonopah Airport from August 29 to December 19, 2007. Integrated samples of $\mathrm{PM}_{10}$ and $\mathrm{PM}_{2.5}$ were collected using FRM samplers on a 1-to-6-day schedule. Two sets of filters (October 10 and November 8, 2007) were analyzed for major anions (sulfate, nitrate, chloride) and cations (sodium and potassium), elements (from sodium to uranium), and elemental and organic carbon. The comparison of $\mathrm{PM}_{10}$ and $\mathrm{PM}_{2.5}$ mass concentrations obtained by continuous monitors and filters showed that differences are associated with the limitations of the instrumentation.

Mean 24-h concentrations of $\mathrm{PM}_{10}$ and $\mathrm{PM}_{2.5}$ mass were 7.6 and $1.7 \mu \mathrm{g} / \mathrm{m}^{3}$, which are significantly lower than the 24-h and annual NAAQS standards $\left(24-\mathrm{h}\right.$ PM $_{10}: 150 \mu \mathrm{g} / \mathrm{m}^{3}, 24-\mathrm{h}$ $\mathrm{PM}_{2.5}: 35 \mu \mathrm{g} / \mathrm{m}^{3}$; Annual $\mathrm{PM}_{2.5}: 15 \mu \mathrm{g} / \mathrm{m}^{3}$ ). Higher $\mathrm{PM}_{10}$ mass concentrations were recorded during the day. Comparatively lower $\mathrm{PM}_{2.5}$ levels were associated with increased wind speeds blowing mostly from the north/northwest in the early afternoon. The chemical composition of both $\mathrm{PM}_{10}$ and $\mathrm{PM}_{2.5}$ samples indicated that organic carbon is the major component of both fractions, while soil contributes approximately 15 to 30 percent of $\mathrm{PM}_{10}$ mass. Sulfate and nitrate account for about 10 percent. Increases in $\mathrm{PM}_{10}$ and $\mathrm{PM}_{2.5}$ mass concentrations were due to higher contributions from organic mass. 


\section{ACKNOWLEDGEMENTS}

Authors thank the Nye County Department of Public Works and James L. Klapper for hosting the mobile trailer at the Tonopah Airport and providing assistance of the installation of electrical power.

\section{REFERENCES}

Engelbrecht, J.P., I.G. Kavouras, D. Campbell, S.A. Campbell, S. Kohl, and D. Shafer, 2007a. Yucca Mountain Environmental Monitoring Systems Initiative. Air Quality Scoping Study for Ash Meadows National Wildlife Refuge, Nevada. Letter Report DOE/NV/26383-LTR2007-01.

Engelbrecht, J.P., I.G. Kavouras, D. Campbell, S.A. Campbell, S. Kohl, and D. Shafer, 2007b. Yucca Mountain Environmental Monitoring Systems Initiative. Air Quality Scoping Study for Beatty, Nevada. Letter Report DOE/NV/26383-LTR2007-02.

Engelbrecht, J.P., I.G. Kavouras, D. Campbell, S.A. Campbell, S. Kohl, and D. Shafer, 2007c. Yucca Mountain Environmental Monitoring Systems Initiative. Air Quality Scoping Study for Rachel, Nevada. Letter Report DOE/NV/26383-LTR2007-03.

Engelbrecht, J.P., I.G. Kavouras, D. Campbell, S.A. Campbell, S. Kohl, and D. Shafer, 2007d. Yucca Mountain Environmental Monitoring Systems Initiative. Air Quality Scoping Study for Sarcobatus Flats, Nevada. Letter Report DOE/NV/26383-LTR200704.

Kavouras, I.G., V. Etyemezian, D. DuBois, J. Xu, M. Pitchford, and M. Green, 2005. Assessment of the Principal Causes of Dust-Resultant Haze at IMPROVE Sites in the Western United States. Final report to Western Regional Air Partnership (www.coha.dri.edu/dust).

Lefer, B.L. and R.W. Talbot, 2001. Summertime measurements of aerosol nitrate and ammonium at a northeastern U.S. site. Journal of Geophysical Research, 106, 20,365 20,378 .

Malm, W.C., B.A. Schichtel, R.B. Ames, and K.A. Gebhart, 2002. A 10-year spatial and temporal trend of sulfate across the United States. Journal of Geophysical Research, 107, 4627, doi:10.1029/2002JD002107.

Malm, W.C., B.A. Schichtel, M.L. Pitchford, L.L. Ashbaugh, and R.A. Eldred, 2004. Spatial and monthly trends in speciated fine particle concentration in United States. Journal of Geophysical Research, 109, D03306, doi:10.1029/2006JD003739.

White, W.H. and P.T. Roderts, 1977. On the nature and origins of visibility-reducing aerosol in the Los Angeles air basin. Atmospheric Environment, 11, 803-812. 


\section{DISTRIBUTION}

Allen Bensen

Yucca Mountain Project Office

Office of Civilian Radioactive Waste

Management

U. S. Department of Energy

1551 Hillshire Drive

Las Vegas, NV 89134

Jan Cameron, Chair

Amargosa Valley Advisory Board

821 E. Farm Road

Amargosa Valley, NV 89020

Jenny Chapman

Division of Hydrologic Sciences

Desert Research Institute

755 E. Flamingo Road

Las Vegas, NV 89119-7363

Linda Cohn

Environmental Protection Team

Nevada Site Office

National Nuclear Security Administration

U.S. Department of Energy

P.O. Box 98518

Las Vegas, NV 89193-8518

Russ Dyer

Yucca Mountain Project Office

Office of Civilian Radioactive Waste

Management

U. S. Department of Energy

1551 Hillshire Drive

Las Vegas, NV 89134

Joni Eastley, Chair

Nye County Commission

P.O. Box 153

Tonopah, NV 89049

Lori Plummer

Environmental Protection Team

Nevada Site Office

National Nuclear Security Administration

U.S. Department of Energy

P.O. Box 98518

Las Vegas, NV 89193-8518
Marjory Jones

Division of Hydrologic Sciences

Desert Research Institute

2215 Raggio Parkway

Reno, NV 89512-1095

Darrell Lacy, Director

Nye County Nuclear Waste Repository

Project Office

1210 E. Basin Rd., Suite 6

Pahrump, NV 89060

Peter Sanders

Environmental Restoration Project

Nevada Site Office

National Nuclear Security Administration

U.S. Department of Energy

P.O. Box 98518

Las Vegas, NV 89193-8518

Reina Serino, Contracting Specialist

Office of Business Services

NNSA Service Center

Pennsylvania and H Street, Bldg. 20388

P.O. Box 5400

Albuquerque, NM 87185-5400

Bonnie Thompson

Water Resources, Nevada District

U.S. Geological Survey

160 N. Stephanie Street

Henderson, NV 89074

Nevada State Library and Archives

State Publications

100 North Stewart Street

Carson City, NV 89701-4285

Archives

Getchell Library

University of Nevada, Reno

DeLaMare Library/262

University of Nevada, Reno

Document Section, Library

University of Nevada, Las Vegas

4505 Maryland Parkway

Las Vegas, NV 89154 
Library

Southern Nevada Science Center

Desert Research Institute

755 E. Flaming Road

Las Vegas, NV 89119-7363

Public Reading Facility

c/o Nuclear Testing Archive

Nevada Site Office

National Nuclear Security Administration

U.S. Department of Energy

P.O. Box 98521, M/S 400

Las Vegas, NV 89193-8521

(CD)
Technical Library

Nevada Site Office

National Nuclear Security Administration

U.S. Department of Energy

P.O. Box 98518

Las Vegas, NV 89193-8518

(CD)

Office of Scientific and Technical Information

U.S. Department of Energy

P.O. Box 62

Oak Ridge, TN 37831-9939

(electronic copy) 